Discussion Paper No. 11-005

Asymmetries and Interdependencies in Time use Between Italian Parents

Anna Laura Mancini and Silvia Pasqua

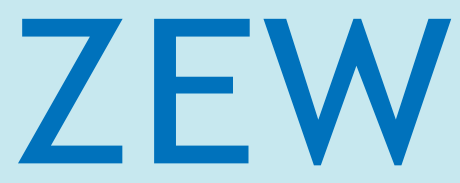

Zentrum für Europäische Wirtschaftsforschung $\mathrm{GmbH}$

Centre for European

Economic Research 
Discussion Paper No. 11-005

\title{
Asymmetries and Interdependencies in Time use Between Italian Parents
}

\author{
Anna Laura Mancini and Silvia Pasqua
}

Download this ZEW Discussion Paper from our ftp server:

ftp://ftp.zew.de/pub/zew-docs/dp/dp11005.pdf

Die Discussion Papers dienen einer möglichst schnellen Verbreitung von neueren Forschungsarbeiten des ZEW. Die Beiträge liegen in alleiniger Verantwortung der Autoren und stellen nicht notwendigerweise die Meinung des ZEW dar.

Discussion Papers are intended to make results of ZEW research promptly available to other economists in order to encourage discussion and suggestions for revisions. The authors are solely responsible for the contents which do not necessarily represent the opinion of the ZEW. 


\section{Non-technical summary}

In recent decades, changes in parents' attitudes towards the importance of spending time with children to optimise their development have greatly affected patterns of time allocation among both working and non-working parents in all developed countries. So far, the research on the time allocation of couples has been focused on how spouses divide their time between work, domestic tasks and childcare, without distinguishing between time spent on basic care and quality time and without considering links between spouses. Moreover, the main concern has been the reduction of maternal caring time due to the increase in mothers' working time. The link between father time with the child and mother's working time is still to be understood. Finally the literature provides evidence that children's achievements depend less on the total time parents devote to them than on the type of activities parents engage in with them. It seems, then, plausible to hypothesize that parents are willing to find substitutes for basic care time (in the form of help from grandparents, babysitters or childcare centres), while preferring to allocate as much of their own time as possible to engaging in "quality" activities with their children.

In this paper we investigate how parents' employment status affects the total time they spend with their children and if it is basic care time or quality time that is affected more. We compare the two waves of the Italian Time Use dataset (1988 and 2002) to analyse how family time allocation changed over time in a country that was undergoing a marked increase in female employment rate and a continuous decline in total fertility rate. Using a simultaneous sequential approach, we consider links among the different time uses of individuals and correlations between spouses' decisions. 
Our results show that women's time allocation is generally more responsive to family and individual characteristics than men's time allocation. Family composition becomes important only in 2002, when fathers are more involved in children caring and education as a response to women's increased participation in the labour market. Substitution by fathers for working mother's time thus seems to be a relatively recent phenomenon. Another interesting result is that mother's education increases the time both parents spend with their children, while father's higher education has an effect on mother's quality care and only in the most recent years. Finally, the number of hours mothers spend at work inevitably decreases both the basic and quality care time they spend with their children, but this is compensated by an increase in the amount of time fathers are devoting to their children. 


\section{Das Wichtigste in Kürze}

In den letzten Jahrzehnten hat sich die Einstellung von Eltern zu der Zeit, die sie mit ihren Kindern verbringen, gewandelt. Dieser Wandel wird an einer veränderten Qualität der Zeitverwendung erkennbar. Gemeinsam verbrachte Zeit wird mehr und mehr mit anspruchsvollen Aktivitäten gefüllt, die die Entwicklung der Kinder voranbringen sollen. Dagegen werden Zeiten, in denen Kinder von ihren Eltern lediglich beaufsichtigt werden, seltener. Dieser Aufsatz geht der Frage nach, inwiefern ein geändertes Erwerbsverhalten der Eltern für die skizzierte Entwicklung verantwortlich ist.

Bislang konzentriert sich die Forschung zur Zeitverwendung von Eltern darauf, wie Mütter ihr Zeitbudget zwischen Erwerbsarbeit, Hausarbeit und Kinderbetreuung aufteilen. Es fehlt die Qualitätsdimension der den Kindern gewidmeten Zeit. In diese Lücke stößt die vorliegende Arbeit, indem sie zusätzlich zwischen einfacher Beaufsichtigung und anspruchsvollen Betreuungsaktivitäten unterscheidet. Eine Hypothese ist, dass Eltern, wenn das Zeitbudget durch Erwerbsarbeit knapper wird, reine Beaufsichtigung - etwa an Babysitter - eher auslagern als anspruchsvollere gemeinsame Aktivitäten. Weiterhin beleuchten wir den Koordinationsprozess zwischen den Eltern. Wie viel und welche Betreuungsaufgaben übernehmen die Väter, wenn Mütter einer Erwerbsarbeit nachgehen?

Die Analyse beruht auf zwei Wellen von Zeitverwendungsdaten aus Italien aus den Jahren 1988 und 2002. Erfasst werden damit die Veränderungen der Zeitverwendung in einem Zeitfenster, in dem die Arbeitsmarktbeteiligung von Frauen spürbar gestiegen und die Geburtenrate absolut gefallen ist. Mit einem simultanen, sequenziellen Gleichungsmodell erfassen wir sowohl die Beziehungen zwischen den verschiedenen Zeitverwendungsmöglichkeiten von Müttern und Vätern als auch die Abhängigkeiten zwischen den Zeitverwendungsentscheidungen beider Elternteile.

Die Ergebnisse zeigen einerseits, dass traditionelle Rollenmuster in Italien nach wie vor prägend sind. Es ist nach wie vor sehr viel häufiger, dass Frauen ihre Zeitverwendung an die Familienverhältnisse, insbesondere die Anzahl und das Alter der Kinder, anpassen als Männer. Hierdurch rücken sie in die Rolle der Zweitverdiener. Andererseits lässt sich anhand der neueren Daten feststellen, dass Väter zunehmend Betreuungsaufgaben übernehmen, wenn ihre Frauen erwerbsbedingt weniger Zeit zur Verfügung haben. Hier scheint ein Rollenwandel auf. Schließlich bestätigen die Ergebnisse die Erwartung, dass sowohl Mütter als auch Väter auf Qualitätszeit mit ihren Kindern zunehmend Wert legen. Dies ist bildungspolitisch bedeutsam, denn anspruchsvolle gemeinsame Aktivitäten können zur Kindesentwicklung langfristig viel beitragen. 


\title{
Asymmetries and interdependencies
}

\author{
in time use between Italian parents
}

\author{
Anna Laura Mancini ${ }^{*}$ \\ and \\ Silvia Pasqua ${ }^{\dagger}$
}

\begin{abstract}
In recent decades, changes in parents' attitudes towards the importance of spending time with children to optimise their future behaviour and cognitive development have greatly affected patterns of time allocation among both working and non-working parents in all developed countries. We compare the two waves of the Italian Time Use dataset (1988 and 2002) to analyze how family time allocation changed over time in a country that was undergoing a marked increase in female employment rate and a continuous decline in total fertility rate. We focus especially on how parents' time with their children depends on their employment status and household characteristics. Using a simultaneous sequential approach, we consider links among the different time uses of individuals and correlations with spouses' decisions. We find that wives' time at work time strongly influences the time spent by both spouses with their children in 2002, but not in 1988. Fathers were much more involved in childcare and rearing in 2002 than in 1988. In general, as women's work time increased, substitutes for their childcare time were found within the household (fathers or other co-resident adults).
\end{abstract}

Keywords: time use, parents, children JEL classification: D1, J13, J22

We would like to thank Daniela Del Boca, Chiara Pronzato and the participants to the Zew Summer Workshop 09 and to the ESPE 09 annual conference for their useful comments and suggestions. The usual disclaimers apply.

\footnotetext{
*Zew and ChilD, mancini@zew.de

† University of Torino - Dipartimento "G.Prato", Collegio Carlo Alberto and ChilD, silvia.pasqua@unito.it

‡ Corresponding author: Silvia Pasqua, E-mail: silvia.pasqua@unito.it; Ordinary mail: Dipartimento di Scienze Economiche e Finanziarie "G. Prato", Facoltà di economia, Corsu Unione Sovietica 218bis, 10100 Torino, ITALY
} 


\section{Introduction}

The increase in female labour force participation, the availability of new technologies for housework and changed attitudes towards the time parents spend with their children for their future behavioural and cognitive development have had a strong impact on the patterns of time allocation of both working and non-working parents in all developed countries (Sayer et al., 2004; Bianchi, 2000; Craig, 2006).

Changes in the time allocation of Italian couples are a particularly interesting case, for although still ranking among the lowest in Europe, Italy's female employment rate has grown steadily over the last 30 years. Over the same period, fertility has sharply declined, while traditional family values persistently steer household decisions. ${ }^{1}$.

We compare the two existing waves of the Italian Time Use dataset (1988 and 2002) to analyze how family time allocation changed over time in a period that saw the female employment rate increase from $34.9 \%$ to $42 \%{ }^{2}$ and the total fertility rate drop from 1.36 to 1.26 . We investigate how parents' time with their children depends on household structure and employment status, focusing especially on the mothers' working time.

The question of mothers' working time is an important one. Data from the US indicate that an increase in mothers' labour force participation reduces not only the number of hours dedicated to childcare, but also the number of children per household. Thus, even if mothers devote less time to childcare overall, no negative effects emerge on individual children's outcomes, since there are fewer children per household who require care (Sandberg and Hoffert, 2001). Moreover, children's academic achievements depend less on the total time parents devote to them than on the type of activities parents engage in with their children (Zick et al., 2001). In addition, changes in social norms regarding parenting imply that parents place a higher value on the time they allocate to childcare and, as a result, women's entry into the labour market has not resulted in a one-to-one decrease in the time they devote to children (Craig, 2006). The effect of women's work on the time fathers devote to their children is

\footnotetext{
${ }^{1}$ According to research by the Fondazione Rodolfo Debenedetti, 35\% of Italian households think that very young children are better staying at home with relatives than going to a crèche (Boeri, Del Boca, Pissarides, 2005).

${ }^{2}$ See OECD (2008).
} 
in contrast more controversial. Nock (1988) and Sundberg and Hoffert (2001), in fact, found that fathers do not compensate for the reduced amount of time mothers spend with their children, while Zick et al. (2001) and Sayer et al. (2004) found that they do.

Most of the literature on the time allocation of couples focuses on how spouses divide their time between work, domestic tasks and childcare, without distinguishing between time spent on basic care and quality time (Kalenkoski et al. 2005, 2006 and 2008; Connelly and Kimmel, 2007; Craig and Bittman, 2008; Mencarini et al., 2004; Anxo et al., 2007; Burda et al., 2006; Bloemen and Stancanelli, 2008; Bloemen et al., 2010). While all of these papers show that working women devote less time to children than non-working mothers, none of them breaks down how that time is actually spent. Yet this is an important distinction to make if we hold that the development of children's future abilities depends on the "quality" of time their parents spend with them. Likewise, it is important to establish not only the extent to which fathers compensate for the reduction in maternal childcare time, but also the sorts of activities they engage in with their children.

Therefore, in addition to investigating how parents' employment status affects the total time they spend with their children, we also need to investigate whether it is basic care time or quality time that is affected more. It seems plausible to hypothesize that parents are willing to find substitutes for basic care time (in the form of help from grandparents, babysitters or childcare centres), while preferring to allocate as much of their own time as possible to engaging in "quality" activities with their children.

While most of the empirical literature on time allocation uses separate Tobit or OLS equations for different time uses, here we use a simultaneous approach to analyse how parents allocate their time between work, domestic tasks, basic childcare and "quality" time with children. We use a Multivariate Tobit model (as in Yen et al., 2005, and Barslund, 2007), which was developed to estimate large censored demand systems. This approach allows us to take into consideration links among the different time uses of individuals and correlations between their spouses' decisions. In addition, we also estimate a sequential model in which the working time of wives and husbands affects - 
both directly and indirectly (through the correlation in the error terms) - other time uses.

To the best of our knowledge, only a few studies ${ }^{3}$ have analysed the time allocation of Italian couples, and only Ichino and and Sanz de Galdeano (2004) differentiates between the time parents devote to their children on quality versus basic care.

In our empirical investigation we find that in 1988 the presence of children in the household did not affect fathers' working decisions and only marginally affected their other time uses, whereas in 2002 fathers were more involved in the caring and rearing of their children. As in Zick et al. (2001) and Sayer et al. (2004), this increase in the time fathers devote to their children seems to be a response to mothers' greater participation in the labour market. In 2002, mothers' work was less responsive to family characteristics. Our findings also indicate that although women allocated more time on average in 2002 to their children than previously, they also relied more on other adults (mainly their partners) for help. Moreover, by distinguishing between quality and basic care activities, we are able to show that mothers tend mainly to delegate basic care activities rather than "quality" time. Our results also indicate that spouses' decisions are correlated, and that this correlation seems to have been greater in 2002.

The paper is organised as follows: Section 2 provides a review of the literature, Section 3 illustrates the data, Section 4 shows our empirical estimation strategy and Section 5 presents the results. Conclusions follow.

\section{Literature}

Pioneering models of time allocation (Becker, 1965; Gronau, 1976) and human capital theories explained that better educated women allocate more time to work and less time to housework. These theories have been developed, extended and tested to include fertility decisions and the effects of children on parents' time allocation and to take into account the role of each spouse's bargaining power in the decision process.

\footnotetext{
${ }^{3}$ Anxo et al. (2007), Mencarini et al. (2004), Ichino and and Sanz de Galdeano (2004), Tanturri and Mencarini and Bloemen et al. (2010).
} 
Most of the empirical literature on couples' time allocation focuses on the effects of children on the time mothers and fathers devote to labour market work and housework. The presence of children in the household reduces the hours mothers participate in the labour market (Kalenkoski et al., 2005), especially in association with the birth of the first child (Craig and Bittman, 2008), while it increases their average hours of domestic work (Craig and Bittman, 2008). Women therefore do most of the extra, unpaid domestic work stemming from the presence of children. Women's education tends to increase their hours of market work, but, ceteris paribus, better-educated women also devote more time to childcare activities (Kalenkoski et al., 2006). At the same time, a father's time with his children increases as his wife's working hours and wages increase (Connelly and Kimmel, 2007; Bianchi, 2000). As a consequence, women's work does not seem to have a strong negative effect on the total time parents devote to their children. However, the amount of time parents spend on childcare drops as the children grow up (Drago and Lee, 2008), and fathers' spend the most time with children when the youngest child is below 3 years of age (Yeung et al., 2001).

By constructing an index of specialization within the couple using time use data Bonke et al. (2007) find that a more egalitarian division of housework emerges when men are more highly educated and where social values are more egalitarian. However, the presence of children always increases specialisation within the household.

There are very few studies on the time allocation of Italian couples. Mencarini et al. (2004) studied data from five Italian cities, finding that men in dual-earner households did not significantly increase their participation in housework after children were born, but increased their time at work instead. More than $10 \%$ of fathers never help with childcare. However, women's education increases the egalitarian division of housework. Tanturri and Mencarini (2009), using a different dataset, confirm that childcare in Italy is mainly a woman's task.

Burda et al. (2006) consider time allocation in four countries, including Italy. For Italy they use, as we do, the Multiscopo dataset for the years 1988 and 2002. In all countries with the exception of Italy, the total work (defined as the sum of market work and domestic work) is roughly equal between men and 
women. In Italy, in contrast, the total work of women exceeds that of men by 72 minutes on a representative day in 1988 and by 75 minutes in 2002. Moreover, men enjoy more leisure than women in both waves. Bloemen et al. (2010) also use the Multiscopo dataset for the year 2002, imputing wage data from a different survey (SHIW). Their results show that time spent by husbands on housework increases with wives' wages, while the time spent by wives decreases. Regarding childcare, the time devoted by fathers increases with their own wage and with the presence of small children in the household, although strong regional differences emerge.

Anxo et al. (2007) compare time allocation over the life cycle in Italy, France, Sweden and the U.S. and find that the gender gap in worked hours in Italy and France increases after union formation. Moreover, after childbirth, Italian women spend 22 additional hours per week on domestic tasks, with men spending only an additional six hours.

The only study examining time allocation of Italian couples that distinguishes between quality and basic care spent by parents with their children is a descriptive paper by Ichino and Sanz de Galdeano (2004), in which the authors compare three countries: Italy, Germany and Sweden. Their results show that when the mother works, basic care time is reduced more than quality care time. Basic care time is reduced by $49 \%$ in Italy, by $40 \%$ in Germany and $3 \%$ in Sweden; quality care time is reduced by $37 \%$ in Italy, $24 \%$ in Germany and by an insignificant amount in Sweden. Interestingly, Italy is the only country where the time devoted to children by other adults increases when the mother works. Among working women, the more educated devote more time to childcare than their less educated peers.

Other studies distinguishing between basic care and quality time refer to other countries, mainly Anglo-Saxon ones. Nock and Kingston (1988) show that dual-earner households spend less time with children than single-earner households, with the main difference being that working mothers devote less time to their children. Fathers seem not to compensate for this reduction in mothers' time, unless she works at night. Nonetheless, the quality time devoted to children when the mother is working only declines slightly, if at all. In fact, Zick et al. (2001) find that when the mother is employed, the quality time spent by both parents on their children actually increases: employed mothers spend 
more time than non-working mothers on reading and helping children with homework while the fathers' overall time with children also grows.

A general trend of increasing quality time and paternal involvement with children emerges when we compare data for the U.S. in the 1960s with that in the1990s (Bianchi, 2000; Sayer et al. 2004). This is undoubtedly attributable to the higher average level of parents' education, which has been shown to have an impact. For example, Craig (2006), using Australian data for the year 1997, finds that parents' education increases time spent with children, mainly in physical care, but that only university education increases quality time. Moreover, the effect of education is stronger for mothers: women with higher educations increase time for paid work and for time with their children, by decreasing the amount of time spent on housework and personal care.

In another paper distinguishing between basic and quality time, GutierrezDomenech (2008) uses the 2002-2003 Spanish time use survey to analyse how parents spend their time with their children in basic and quality activities according to their working status. She finds that Spanish women perform almost all primary basic childcare activities, but that primary quality childcare is shared by the parents. Moreover, working and non-working fathers spend the same amount of time on childcare. The education level of both parents increases the time spent with children. Spanish data also seem to indicate that working mothers tend to prioritise quality childcare time over basic care time in their time allocation decisions. These findings are particular relevant to our study, given the similarities between Spanish and Italian culture.

From the methodological point of view, many of the studies cited above rely mainly on descriptive statistics or on the estimation of separate equations linear or Tobit - for each time use (for example Ichino and Sanz De Galdeano, 2004, Zick et al., 2001, Burda et al., 2006, and Mencarini and Tanturri, 2004). Some studies, like Gutierrez-Domenech (2008), use a two-step instrumental variable approach ${ }^{4}$ to eliminate the simultaneous equation bias. Bloemen et al. (2010) and Kalenkoski et al. (2006) use, as in the present paper, a multivariate Tobit model where the time uses of each spouse are correlated to those of the other spouse through the unobservables. However, Bloemen et al. (2010) do not consider the distinction between the time devoted to basic and quality

\footnotetext{
${ }^{4}$ They instrument childcare time using the previously predicted working time.
} 
childcare, while Kalenkoski et al. (2006) do not take into account housework time. Moreover, neither considers both the direct and indirect impact of each spouse's working time on his/her own other time uses or on the time uses of the spouse, as we do in our sequential model.

\section{Strategy for empirical estimation}

We are interested in estimating the effect of different individual and family characteristics on husband and wife time allocation decisions and the possible correlations among decisions.

We imagine a typical model of household decisions in which husband and wife maximize the household utility function that can be thought as the averaged sum of the utilities of the two spouses that depend on the consumption of market goods, on home produced goods, on leisure time and on the quality of children. Market goods and leisure are pure private goods, while both home produced goods and child quality are "public goods" for the couple that can be produced with spouses' time and/or with goods bought on the market. The household utility is maximised subject to a household budget constraint, to each spouse's time constraint and to a household production function (for home produced goods). The solution of the model gives the time allocation chosen by each parent, i.e., how each spouse divides his/her total time between work, domestic activities, basic childcare and quality care time ${ }^{5}$. The decisions are taken simultaneously and they are all affected by individual and family characteristics and by social background. Given the nature of public goods for the couple of both domestically produced goods and child quality and given the unique household's budget constraint, spouses' decisions are interdependent. Depending on the functional form of the utility functions, the model can produce corner solutions, meaning that each individual may allocate zero time to one or more uses.

We do not set out to estimate a full structural model, since we want to specify neither a functional form for the utility function nor the form of spouses' interactions. We will nevertheless use a model that takes into account that the time allocated by each spouse to different activities is jointly decided and, therefore, that there are interdependence in spouses' time decisions. We will

\footnotetext{
${ }^{5}$ Leisure is the residual time category
} 
handle the existence of corner solutions by using limited dependent variable models. For these reasons, we estimate the following interdependent simultaneous equations:

$$
\begin{aligned}
& \left\{\begin{array}{l}
h_{k}^{*}=\alpha_{0 k}+\alpha_{1 k} X_{m}+\alpha_{2 k} X_{f}+\alpha_{3 k} F+\alpha_{4 k} Y+\varepsilon_{h k} \\
d_{k}^{*}=\beta_{0 k}+\beta_{1 k} X_{m}+\beta_{2 k} X_{f}+\beta_{3 k} F+\varepsilon_{d k} \\
b c_{k}^{*}=\gamma_{0 k}+\gamma_{1 k} X_{m}+\gamma_{2 k} X_{f}+\gamma_{3 k} F+\varepsilon_{b c k} \\
q c_{k}^{*}=\varphi_{0 k}+\varphi_{1 k} X_{m}+\varphi_{2 k} X_{f}+\varphi_{3 k} F+\varepsilon_{q c k}
\end{array} \quad k=(m, f)\right. \\
& \left\{\begin{array}{l}
h_{k}=\max \left(0, h_{k}^{*}\right) \\
d_{k}=\max \left(0, d_{k}^{*}\right) \\
b c_{k}=\max \left(0, b c_{k}^{*}\right) \\
q c_{k}=\max \left(0, q c_{k}^{*}\right)
\end{array}\right.
\end{aligned}
$$

where $h_{k}$ is work time for individual $k, d_{k}$ is domestic time, $b c_{k}$ is time for basic care and $q c_{k}$ is time for quality care; $X_{m}$ are husband characteristics, $X_{f}$ are wife characteristics, $F$ are family characteristics and $Y$ are wealth controls that affect only labour supply 6 .

As pointed out in Hallberg and Klevmarken (2003), our equations are not Marshallian demand functions ${ }^{7}$ because they do not depend on wages. They are behavioural equations derived from the first-order conditions of the optimization problem of the household.

A different model of household time allocation can be imagined in which time uses are not all simultaneously decided. Work time is, in fact, the most difficult time use to be adjusted at the intensive margin: flexibility in the number of working hours depends upon the type of contract, the type of job and the employer and, therefore, the decision is mainly whether or not to work. Therefore, it is likely that working hours depend not directly on the other

\footnotetext{
${ }^{6}$ Given the types of wealth controls available in our dataset, we believe that $Y$ directly affects only the amount of time dedicated to paid work. It is, in fact, unlikely that families rely on wealth to pay for housework or child care substitutes. Generally, the decision to use housework or childcare services depends more on income, i.e., mainly paid work. Nevertheless, we run a sensitivity analysis including the wealth controls in all our equations. Results are robust and the wealth variables included in $\mathrm{Y}$ were never significant in the non-work time use equations.

7 In the empirical analysis, we disregard the price of market substitutes for home production, since they are not known.
} 
possible time uses, but only indirectly, through error correlation. Moreover, woman's labour supply is often considered more flexible and adaptable to household domestic and childcare needs (Craig and Sawrikar, 2009). It is therefore likely the time devoted by the spouses to domestic and childcare activities depends directly on how much time they, and particularly the woman, commit to work. Additionally, children need a minimum amount of basic care time, while "quality" time is not strictly necessary. At the same time, it is easier to find substitute providers for basic care than for quality care activities. Therefore, parents first decide how much time they want to devote to basic childcare and only then to how much time they want to devote to quality care.

We thus assume a sequence of time allocation decisions in which spouses first decide how much time they want to devote to market work and only then to how to divide the residual time between domestic work, basic care, quality care and other activities (leisure). Moreover, we model each spouse's quality care time use as dependent directly on his/her own basic care time. Therefore, in our empirical model, domestic time, basic care and the quality care of both spouses depend on both spouses' work time, while the husband's and wife's quality time depends on each of their own basic care time. The simultaneous equations system becomes:

$$
\begin{aligned}
& \left\{\begin{array}{l}
h_{k}^{*}=\alpha_{0 k}+\alpha_{1 k} X_{m}+\alpha_{2 k} X_{f}+\alpha_{3 k} F+\alpha_{4 k} Y+\varepsilon_{h k} \\
d_{k}^{*}=\beta_{0 k}+\beta_{1 k} X_{m}+\beta_{2 k} X_{f}+\beta_{3 k} F+\beta_{4 k} h_{f}+\beta_{5 k} h_{m}+\varepsilon_{d k} \\
b c_{k}^{*}=\gamma_{0 k}+\gamma_{1 k} X_{m}+\gamma_{2 k} X_{f}+\gamma_{3 k} F+\gamma_{4 k} h_{f}+\gamma_{5 k} h_{m}+\varepsilon_{b c k} \\
q c_{k}^{*}=\varphi_{0 k}+\varphi_{1 k} X_{m}+\varphi_{2 k} X_{f}+\varphi_{3 k} F+\varphi_{4 k} h_{f}+\varphi_{5 k} h_{m}+\varphi_{6 k} b c_{k}+\varepsilon_{q c k}
\end{array} \quad k=(m, f)\right. \\
& \left\{\begin{array}{l}
h_{k}=\max \left(0, h_{k}^{*}\right) \\
d_{k}=\max \left(0, d_{k}^{*}\right) \\
b c_{k}=\max \left(0, b c_{k}^{*}\right) \\
q c_{k}=\max \left(0, q c_{k}^{*}\right)
\end{array}\right.
\end{aligned}
$$

We expect the mother's work coefficients to be more significant than the husband's, because men's work is rather stable across families (Italian men almost always work full time) while women's work is more flexible and thus 
heterogeneous. A negative sign of a spouse's work coefficient on his/her own time uses ( $\beta_{4 \mathrm{f}}, \gamma_{4 \mathrm{f}}$ and $\varphi_{4 \mathrm{f}}$ for mothers and $\beta_{5 \mathrm{~m}}, \gamma_{5 \mathrm{~m}}$ and $\varphi_{5 \mathrm{~m}}$ for fathers) points toward a substitution effect between individual time uses. A positive sign of a spouse's work coefficient on the other spouse's time uses $\left(\beta_{4 \mathrm{~m}}, \gamma_{4 \mathrm{~m}}\right.$ and $\varphi_{4 \mathrm{~m}}$ and $\beta_{5 f}, Y_{5 f}$ and $\varphi_{5 f}$ respectively), instead, suggests a compensation mechanism between spouses' time allocations. Finally, we expect the basic care coefficient $\varphi_{6 k}$ to be negative and significant for both spouses, because it should capture the joint effect of the time constraint and the minimum amount of basic care need by children.

All the errors are assumed to be identically and independently jointly normally distributed with an unrestricted covariance matrix.

$$
\left(\begin{array}{c}
\varepsilon_{h m} \\
\varepsilon_{h f} \\
\cdots \\
\varepsilon_{q c m} \\
\varepsilon_{q c f}
\end{array}\right)=\left(\left(\begin{array}{c}
0 \\
0 \\
\cdots \\
0 \\
0
\end{array}\right),\left(\begin{array}{ccccc}
\sigma_{h m}^{2} & \sigma_{h m, h f} & \cdots & \cdots & \sigma_{h m, q c f} \\
\sigma_{h m, h f} & \sigma_{h f}^{2} & \cdots & \cdots & \cdots \\
\cdots & \cdots & \cdots & \cdots & \ldots \\
\cdots & \ldots & \cdots & \cdots & \cdots \\
\sigma_{h m, q c f} & \ldots & \cdots & \ldots & \sigma_{q c f}^{2}
\end{array}\right)\right)
$$

where $\sigma_{i}^{2}$ is the variance of the $\varepsilon_{i}$ and $\sigma_{i j}$ is the covariance between $\varepsilon_{i}$ and $\varepsilon_{j}$. Correlation in unobservables among the errors of the eight time-use equations may arise from unobserved household-specific correlations in preferences or productivity. Rather than using a 3SLS as in Hallberg and Klevmarken (2003), we estimate our models (both the simultaneous and the sequential) as Seemingly Unrelated Regressions system. In particular, we draw from the literature on large censored demand systems and we estimate two multivariate Tobit models (for details, see Yen et al., 2005, and Barslund, 2007). Observations that are censored in three or more equations involve calculation of a cumulative jointly normal distribution up to eight dimensions, depending on the number of non-negative binding constraints. To solve this problem, we use the GHK algorithm developed by Börsh-Saupan and Hajivassiliou (1993), Hajivassiliou and McFadden (1990) and Keane (1994). This algorithm evaluates the probability each individual contributes to the likelihood exploiting the fact that a multivariate normal distribution function can be expressed as the product of sequentially conditioned univariate normal distribution functions. Finally, as 
pointed out by Greene (2003), in limited dependent variables models with simultaneous equations the endogeneity of one or more variables can be ignored in formulating the likelihood if the system is sequential (with a triangular coefficient matrix) and if the endogenous variables enter the subsequent stages as observed ( $h$ and not $h^{*}$ ). Therefore, in our sequential model we introduce working time and caring time as observed in our sample in the following time use equations without modifying the likelihood.

\section{Data and sample selection}

We investigate the time allocation of Italian families using data from the national time use surveys 1988-89 and 2002-03, "Indagine Multiscopo sulle Famiglie - Uso del Tempo", carried out by the Italian National Statistical Office (ISTAT). The 1998 dataset covers 13,729 households corresponding to 38,110 individuals while the 2002 wave covers 21,075 households corresponding to 55,773 individuals, including children and other adults living in the household.

An individual questionnaire containing socio-demographic information and a time diary were collected. All members older than three years ${ }^{8}$ completed the time diary on a selected day. In each municipality covered by the survey, households were divided into three groups and each group was asked to fill in the daily diary at a different time: a weekday, Saturday or Sunday ${ }^{9}$. Our analysis is based on diaries completed on weekdays.

This dataset has the advantage of being representative of the Italian population and of requiring all household members to fill in a time diary. Its main disadvantage is that no information was collected on earnings or income.

The diary reports information on the time spent on a large number of tasks. Activities were coded by the respondent as main or secondary activities ${ }^{10}$. In addition, the respondent specified if the activity was carried out with another family member and if this member was a child younger that ten.

The data allow us to construct three different definitions of childcare: primary childcare, when the main activity is reported as childcare, secondary childcare, when childcare is defined as a secondary activity, and passive

\footnotetext{
${ }^{8}$ The time diary of very young children was completed by parents.

${ }^{9}$ The oversampling of weekend diaries was a deliberate choice of the data collector (ISTAT).

${ }^{10}$ For example, someone may be cooking and watching television or cooking and looking after the children. It is the respondent that chooses which of the activities is the main one and which is the secondary one.
} 
childcare, when parents report any activities with a family member younger than ten years old. Primary and secondary childcare could be divided in two subgroups according to the type of activities parents do with their children. Basic childcare includes all activities related to the child's essential needs, e.g., feeding, dressing, bathing, while quality childcare refers to activities related to children's educational, cultural and emotional development. Quality childcare is generally understood to be more effective in fostering children's development.

Distinguishing between primary, secondary and passive childcare and between basic and quality childcare is very important in order to understand if the time spent with children is reduced in families where both parents work and, if so, what kind of time is reduced. Primary childcare is the definition that best reflects parents' decision to commit time to their child, because it requires the highest degree of parental involvement among the above described definitions. Moreover, secondary childcare and passive childcare are more dependent on how the parents fill in the diary ${ }^{11}$. Therefore we focused our analysis only on primary childcare and distinguished between time spent with children on basic care and on quality care.

\subsection{Sample selection and time categories}

For our empirical analysis we construct one sample for 1988 and one for 2002. In both years we selected only married or cohabiting couples in which both partners were older than 18 and younger than 56 years at the time of the interview and with at least one child younger than 14. We excluded couples for which the weekly diary was filled in during the weekend or on a "special" day (on a vacation day or a sick day, for example) ${ }^{12}$. We also excluded couples in which one (or both) spouse(s) was enrolled in full-time education, retired, disable, chronically ill or doing military service ${ }^{13}$. We were also forced to exclude single parents because the sub-sample size was too small, especially in $1988^{14}$. Finally, we excluded all households in which one or more variables used in the analysis were missing. Table 1 shows the construction of our two samples. In

\footnotetext{
${ }^{11}$ For example, in the 1988 survey, almost no one reported childcare as a secondary activity, whereas in 2002 parents often did.

${ }^{12}$ In 2002 we were also able to exclude couples in which the mother is on compulsory maternity leave

${ }_{13}^{13}$ It is likely that in these type of household, in fact, time allocation process works differently.

${ }^{14} 69$ observations in 1988 and 288 in 2002.
} 
both years, the most significant reduction in the size of the sample is due to the selection of spouses of working age with at least one child younger than 14 and who filled in the diary on a normal weekday ${ }^{15}$.

Our final samples consist of 665 households in 1988 and 1,259 households in 2002.

As already mentioned, our main interest was to understand how husbands and wives allocate their time into four different activities: market work, domestic work, basic childcare and quality childcare. The empirical definitions of our four time categories are reported below.

Market work: time in paid job (main or secondary); coffee breaks and other breaks during the job; other activities related to employment, excluding job searching activities.

Domestic work: food management and preparation; housekeeping; laundry; ironing; shopping, commercial and administrative services.

Basic care: physical care; supervision; taking to school or to other child's activities.

Quality care: doing homework with the child; playing with the child; reading to the child; reading with the child; talking to the child; watching children's movies and shows.

Tables 2 and 3 show some summary statistics on time allocation in 1988 and 2002 according to the mother's working status ${ }^{16}$. We divide couples into two main types: dual earner households (44.5\% in 1988 and 50\% in 2002) and male breadwinner households (51.3\% in 1988 and 46.6\% in 2002). Residual categories were female breadwinner and no breadwinner (where both spouses are unemployed). Because the latter two categories were too small $(4.2 \%$ in 1988 and $3.3 \%$ ) to give reliable descriptive statistics, they are not reported. Table 2 reports the unconditional mean of work time, domestic time, basic care and quality care while Table 3 shows the ratio of individuals with non-zero values in each time category and the means conditioned on declaring a positive value $^{17}$.

\footnotetext{
${ }^{15}$ The effect of the sample selection on the variables most relevant in the analysis is not presented. Available to the authors upon request.

${ }_{17}$ An individual is classified as "working" when he/she declares to be employed.

17 A well-known problem in time use studies is that the time diary reflects a one day time allocation and it is possible that individuals do not engage that day in some activities they
} 
Work time was significantly higher in 2002 than in 1988 for both men and women. In both periods, housework accounted for the largest part of a female's tasks, even if wives' domestic time had dropped significantly in 2002. Husband's domestic time, instead, underwent fewer variations between 1988 and 2002, but the amount of time fathers spent with their children increased significantly. At the same time, the amount of time mothers devoted to children also increased. When mothers do not work, fathers seem to be less involved in basic childcare tasks, and the time they spend with the children is more oriented towards quality time. When mothers work, the amount of time fathers spend with their children increases, mainly due to an increase in basic childcare time rather than quality care time.

Looking at Table 3, we notice that parents who allocate time to childcare activities (i.e., those with positive values) always allocate a significant amount of time: at least half an hour in basic care and almost one hour in quality care per day. Moreover, not only did both mothers and fathers increase the time spent with children from 1988 to 2002 (higher conditional means), but also the number of parents spending time with their children grew. In 1988, among dual earners couples, $24.7 \%$ of fathers and $72.3 \%$ of mothers declared a positive amount of basic care, while in 2002 the percentages raise to $47.7 \%$ and $83.2 \%$ respectively. In 1988, among male breadwinner families, $16.7 \%$ of fathers and $31.4 \%$ of mothers spend quality time with their children, while in 2002 the percentages grow to $41.4 \%$ and $61.8 \%$ respectively.

In Table 4 we report the unconditional average time spent on each activity by the two spouses as a function of each spouse's education level. The total impact of parental schooling on different time uses is not clear a priori. It is proven that education increases market work, but the effect of education on other activities is uncertain and depends crucially on how parents value childcare time relative to other possible time uses. It seems reasonable to expect a positive correlation between education and childcare time (in particular quality care time) and a negative correlation between education and domestic work time. Domestic work time, in fact, is a low-human-capital activity easily substitutable with goods and services bought in the market, while the opposite is true for childcare, especially for quality care. 
In both 1988 and 2002, female university graduates spent more time on paid work and less time on domestic work than women with compulsory education or less. In 1988, the husband's education had a U-shaped effect on own time in domestic work, with the exception of middle educated husbands of middle educated wives, and the higher the wife's education the lower the husband's domestic work. Twelve years later, things changed: the husband's education had a reverse U-shaped effect on husband's domestic work (secondary school husbands do more domestic work than compulsory and college-educated husbands) and the wife's education increased the husband's domestic work.

In 2002, fathers with a secondary school degree allocated the highest time to childcare tasks, both care and quality care, while in 1988, they increase with husband's educational level. Childcare time increases with mothers' educational level, too, but highly educated women married to highly educated men decrease their childcare time supply. The higher the education level of the wife, the more time their husbands allocate to childcare.

\subsection{Variables}

Our dependent variables are the four time categories: market work, domestic work, basic care and quality care.

We consider both individual's characteristics, household characteristics as independent variables, and we control for the geographical area of residence.

To capture the effect of parental education, we use compulsory education (8 years of schooling) as the reference group. The other educational levels that can be distinguished are lower 'secondary education' (2 years of secondary school); upper secondary education (5 years of secondary school); a short university degree (2 years); and a standard university degree (4 or more years). These last two categories are aggregated together in the estimation of the model, as there are few individuals in the dataset with a short university degree. For the same reason, we also aggregate lower and upper secondary schooling,

We use dummy variables for the age of the youngest child in the household. We distinguish two categories: the youngest child is (i) younger than 3 years and (ii) from 3 to 5 years old. We distinguish between these two categories because the availability of childcare facilities for children below the 
age of 3 is very limited in Italy, especially in the Southern regions of the country, while public childcare covers on average $95 \%$ of the population of children from 3 to 5 (Del Boca et al., 2007 and 2009).

We also include the total number of children living in the household, since the higher the number of children, the more the time parents need to devote to them. However, the amount of time required should increase less than proportionally with respect to the number of children, due to economies of scale.

We control for the presence of healthy adults other than the parents in the household (grandparents, adult children, other parents) ${ }^{18}$. Their role could be two-fold: they might either help the family by providing free childcare services, and they might also be an income source.

We include three regional dummies to capture systematic differences across different parts of Italy. Living in the North is our reference group, compared to living in the Centre and living in the South. Households that reside in different parts of Italy face different unemployment rates and labour market conditions, different childcare availability and different living costs, all elements that could strongly affect time allocation decisions.

Unfortunately, the dataset contains no information about the wealth or income of the family and we have almost no variables allowing us to proxy the economic situation of the household. Richer families can more easily purchase substitutes for their time uses (for example, wealthier families can afford a housekeeper), and from this and other information, we try to recover some economic controls from the two waves. In both years, we construct a dummy equal to 1 if the family owns the apartment or the house they live in. Home ownership is the first and main investment an Italian family makes whenever possible. Families that do not own the apartment/house are often families that cannot afford to do so. In the 1988 sample, we also construct a dummy variable equal to 1 if the family lives in subsidized housing, as an indicator for families that are in the lowest part of the income distribution. Unfortunately, the 2002

\footnotetext{
${ }^{18}$ We tried to control also for the presence of sick adults within the household. In general, sick adults play a competing role with children for the wife (but also for the husband) time, since they need care for themselves, and their care might also require additional expenses. However, in 1988 the sickness status is based on a question that asks if the individual is chronically ill, while in 2002 is based on a self-reported variable on the individual health status, with possible answers that varies from very good to very bad. Therefore, even if our results were robust to the inclusion of the dummy "sick adults", we were not convinced by the comparability of the two definitions and therefore we preferred not to include the variable in the estimates here presented.
} 
dataset does not include the same information, so we control for the family owning a holiday house as an indicator of belonging to the upper part of the income distribution. We also define another dummy for 2002 to control for those families that declare that they are poor or very poor on the basis of the survey question 19 "How do you define the economic situation of your family?"

Table 5 reports sample summary statistics for the years 1988 and 2002.

The 2002 sample is older than the 1988 one. Education increased drastically in 2002 with respect to 1988 for both men and women. In particular, the number of men and women with at least a secondary school education grew significantly, as did the percentage of women with a university degree. More women worked in 2002 than in 1988, but strong regional differences in female employment rates persists over time. In fact, in both years, women are much more likely to be housewives if they live in Southern regions than in Northern regions. The number of children per household decreased slightly, from 1.95 to 1.84. Looking at our wealth controls, the ratio of homeowners rose from $65.6 \%$ to $67.7 \%$. In $2002,11.5 \%$ of households have a holiday house and $6.4 \%$ feel that they are poor or very poor. In $198827.4 \%$ of households lived in subsidized housing.

\section{Results}

We estimate the two models described in Section 3 separately for the two years. The first model, called the simultaneous model, is a SUR system of eight left-censored Tobit equations without endogenous variables. In the second model, called the sequential model, we estimate a SUR system of eight leftcensored Tobit equations in which we allow domestic time, basic care and quality care depend directly on the husband's and wife's observed working hours; the husband's and wife's quality care time depends directly on their own basic childcare.

Table 6 shows the estimation results of the simultaneous model for wives and Table 7 for husbands. In general, the wife's time allocation is more

\footnotetext{
${ }^{19}$ Since it is a self-reported variable, it depends crucially on individual beliefs and it is likely to be downward bias and centered around the mean (as it is). Nevertheless, we think that those individuals who report to be poor or really poor are likely to be families that suffer for some kind of real economic constraints.
} 
responsive to family and individual characteristics than the husband's in both years.

The wife's education has a positive impact on her working hours which is stronger in 2002 than in 1988, but it has a negative impact on the husband's time at work, although this is statistically significant only in 1988 and when the wife has a secondary degree. More highly educated women spend significantly less time doing domestic work in both years. In 1988, the wives of collegeeducated husbands also spend less time doing domestic work, while husbands with a secondary school degree increase their domestic time significantly in 2002. In 1988, the wife's education has a positive effect on the time both parents spend on basic care, while in 2002 this positive effect holds only for the wife's secondary school degree on the husband's basic care. The educational level of the parents plays no significant role in spouses' quality time in either year.

In both years, living in a Southern region significantly decreases the time devoted to market work by both parents, but increases the amount of quality time mothers devote to their children. However, it also increases the time spent by wives on domestic work and reduces husbands' domestic time (although to a lesser extent in 2002 than in 1988). Thus, it is not true (at least in the South) that mothers who work less spend more quality time with their children: they spend more time cleaning the house. Living in central regions, in 2002 is associated with husbands spending less time both on housework and on basic care for children.

In both in the dataset, having at least one child younger than 6 has no effect on either spouses' work time or on the father's domestic time; however, it has a decreasing negative effect on mother's domestic time in 2002. Parents allocate more time to both basic and quality care in both years if they have children younger than 6 , but this positive effect decreases with the child's age. In particular, having a child younger than 3 increases parents' basic care in both 1988 and 2002, and having at least one child between 3 and 5 increases both parents' basic care in 2002 and the mother's basic care in 1988. Having at least one child under 6 positively influences the mother's quality time, too, but only in 2002, whereas it has a positive effect on father's quality care in both years. 
The number of children in the household has a significant negative effect on the time devoted by mothers to market work, although to a lesser extent in 2002 than in 1988. The number of children has a positive effect on the father's time at work, but the difference is significant only in 2002. In the same year, the number of children has a positive effect on the time women spend on basic child care as well as on the time they spend doing housework (both 1988 and 2002), while it has a negative effect on the husband's quality time in 2002.

In 2002, living with other adults significantly decreases the basic care time of both parents, as expected, but also the quality care time of both.

These results seem to support the fact that the male breadwinner family, where the man provides the income and the woman provides domestic work and care, is still a strong reference model for Italian couples.

Finally, home ownership had a positive effect on both spouses' work time, but only in 2002. This effect is probably related to mortgage payment needs. Perceived poverty had the reverse effect, decreasing both parents' work time. This variable could capture negative psychological (discouraged worker) and social effects associated with poverty.

In the simultaneous model we can examine the effect of wives' work on the time parents devote to their children only if we look at the correlations in the error terms (Table 8). The variances of the unobservables of the eight time use equations are always statistically significant, and we find a significant negative correlation across unobservables between the wife's work and the wife's basic and quality care, and a positive correlation between the wife's work and the husband's basic and quality care both in 1988 and in 2002 (although not significant in 2002). Moreover, in our basic model, the husband's work time is negatively related to the husband's type of care both in 1988 and in 2002. This indicates that the same unobservable characteristics that increase labour supply also decrease the time devoted children. However, fathers with working wives are more willing to take care of their children.

The sequential model allows us to go one step further to also measure the direct impact of wife's work on childcare time.

Table 9 and Table 10 report the results of the sequential model for wives and husbands. Most of the results of the simultaneous model are confirmed. This means that education and work time coefficients are actually capturing two 
distinct effects: the first is related to personal characteristics and to the social background, while the second is related to the pure time constraint. For both parents, the time spent on domestic tasks is less responsive to spouses' education. In 1988, the wife's education had a positive effect on the husband's basic care but not on her own care, while the reverse is true in 2002. In contrast to what was revealed by the simultaneous model, the wife's education proves to have a positive effect on both the wife's and husband's quality care in 2002.

Living in the South decreases the mother's basic and quality care (the coefficients of the variable "South " becomes weakly significant and negative in 2002).

Looking at work time coefficients, the wife's work time decreases her domestic time as well as both her care and quality time with children in 2002. The effect on the wife's basic care changed over time: it was positive and significant in 1988 and it became negative and significant in 2002. It seems that women were more time constrained in 2002 than in 1988, so more time at work was reflected in less time dedicated to all other activities. The effect of the wife's working hours on the father is almost null in 1988 but becomes positive in 2002: the more she works, the more time he allocates to domestic work and to basic care. The effect on quality care is positive in 2002, but not statistically significant. Thus, in 2002, fathers compensate for the loss in maternal time by dedicating more time to the basic care of their children.

The husband's work time had a negative effect on basic care and quality care of both spouses in 2002, but no statistically significant effect in 1988. It also had a negative effect on spouses' domestic time. An income effect seems to prevail when we look at the husband's working decisions: couples with higher incomes buy substitutes for time in domestic activities.

Finally, as expected, basic care time had a negative effect on quality time with children. This negative effect was weaker in 2002 than in 1988 for women, while the opposite was true for men.

By comparing the results for the sequential model in the two years, we get some interesting results. Fathers were, in fact, more involved child rearing and childcare activities in 2002 than in 1988. Moreover, living with other adults helped parents manage both basic and quality care; this was particularly true in 2002, when time constraints seemed to be more stringent. Mothers worked 
more in 2002 and allocated less time to their children, relying more on other adults for help (mainly fathers, but also other family adults).

Table 11 reports the correlation matrix for the sequential model. When we control for the direct effect of the wife's work time on other time uses, we find a negative correlation in 1988 between the wife's work and her basic care time that becomes positive in 2002, while the negative correlation with husband's basic care found in 1988 is no longer significant in 2002. The correlation between the wife's work and the husband's quality care in the sequential scenario is positive and significant both in 1988 and in 2002. Again, the father's time allocation in 2002 seems to compensate for the reduction in maternal time. Moreover, in 2002, the husband's work time becomes positively correlated to both types of care time (whereas the sign was positive only for basic care in 1988) and also to maternal care time.

It seems that in 2002 spouses tended to coordinate their time allocation by substituting one spouse's time with the other spouse's time.

In 2002, the wife's basic care was positively correlated with the husband's basic care and with both parents' quality care, and the husband's basic care was positively correlated with the wife's basic care and both parents' quality care. These results imply that parents who spend more time with their children tend to divide it between basic and quality care.

Finally, we test the specification of our sequential model of time allocation against the non-sequential, more traditional simultaneous one using a Wald test on the null of work coefficients and basic care coefficients jointly equal to zero. Our test strongly rejects, on both years, the null. We conclude that our sequential specification is better than our basic specification.

\section{Conclusions}

This paper uses the two existing waves of the Italian Time Use dataset (1988 and 2002) to analyze family time allocation decisions and their changes over time in a period that showed an increase in female employment rate and a decline in total fertility rate.

We use two models, one simultaneous and one sequential, to take into consideration both the direct and the indirect links among different time uses for the individual and the correlation between spouses' decisions. 
Our results show that women's time allocation is generally more responsive to family and individual characteristics than men's time allocation. This seems to indicate that women are still considered as secondary earners in the household. Women's time allocation, in fact, depends strongly on the presence, the age and the number of children. Craig and Sawrikar (2009) found a similar result for Australia: women are more likely to adjust their hours of work as family commitments change. The presence of children in the household, instead, did not affect fathers' working decisions in 1988, becoming important only in 2002, when fathers were more involved in children caring and education as a response to women's increased participation in the labour market. Substitution by fathers for working mother's time thus seems to be a relatively recent phenomenon. Similar results have been obtained in other studies comparing time allocation in the U.S. in different years (Bianchi, 2000, and Sayer et al., 2004).

Another aspect that appears is that mothers' work is less responsive to family characteristics in 2002 than in 1988. Although they allocate more time on average to their children, childcare time diminishes with their work time, even though they rely more on other adults help (mainly on spouses) for childcare. However, in 2002 the indirect (through error terms) effect of mother's working time becomes positive and significant on both quality and basic childcare, meaning that the same unobservables that increase labour supply of mothers also tend to increase the time devoted to children (both by the mother and by the father).

Women's education increases both the time mothers spend with their children and the time fathers spend with their children (although only for basic care in 1988), while men's higher education has an effect on woman's quality care (only in 2002). Surprisingly, men's education has no effect on either the care or quality time they spend with their children.

Despite the traditional household model of Italian couples, these results seem to be consistent with those found for other countries, confirming that parents are placing higher value on the time they spend with their children,; this can be seen in the increase in time they devote to "quality" activities. The implications of this for children's development processes and outcomes are therefore very important in terms of policy implications. The number of hours 
mothers spend at work inevitably decreases both the basic and quality care time they spend with their children, but this is compensated by an increase in the amount of time fathers are devoting to their children. Unfortunately, no datasets are currently available on child outcomes for Italy, making it difficult to analyze the consequences on children of these relevant changes.

\section{Bibliography}

Anxo D. Flood L., Mencarini L., Pailhé A., Solaz A. and Tanturri M.L. (2007), Time Allocation between Work and Family over the Life-Cycle: a Comparative Gender Analysis of Italy, France, Sweden and US, IZA DP No. 3193

Barslund, M. (2007), "Estimation of Tobit Type Censored Demand Systems: a Comparison of Estimators", Discussion Papers, 07-16, University of Copenhagen. Department of Economics

Becker G. S. (1965), A Theory of the Allocation of Time, The Economic Journal, Vol. 75 , No. 299, pp. 493-517

Bianchi S. (2000), Maternal Employment and Time with Children: Dramatic Change or Surprising Continuity?, Demography, vol. 37(4), p. 401-414

Bloemen, H. and Stancanelli E. (2008), How do spouses allocate time: the impact of wages and income, IZA DP No. 3679, September

Bloemen, H., Pasqua S. and Stancanelli E. (2010), An Empirical Analysis of the Time Allocation of Italian Couples: Are Italian Men Irresponsive?, forthcoming Review of Economics of the Household

Boeri T., Del Boca D. and Pissarides C. (eds.), (2005), Women at Work. An Economic Perspective, Oxford University Press

Bonke J., Deding M., Lausten M. and Stratton L. (2007), Intrahousehold Specialization in Housework in the United States and Denmark, IZA DP No. 2777

Börsh-Saupan, A. and Hajivassiliou, V. (1993),"Smooth unbiased multivariate probability simulator for maximum likelihood estimation of limited dependent variable models", Journal of Econometrics, 58(3),pp.347-368 
Burda M., Hamermesh D.S. and Weil P. (2006), The Distribution of Total Work in the EU and US, mimeo

Connelly R. and Kimmel J. (2007), Spousal Influences on Parents' Non-Market Time Choices, IZA DP No. 2894

Craig L. (2006), Parental Education, Time in Paid Work and Time with Children: an Australian Time-Diary Analysis, The British Journal of Sociology, vol. 57(4), p. 553-575

Craig L. and Bittman M. (2008), The Incremental Time Costs of Children: an Analysis of Children's Impact on Adult Time Use in Australia, Feminist Economics, vol. 14(2), P. 59-88

Craig L. and Sawrikar P. (2009), Work and Family: How Does the (Gender) Balance Change as Children Grow?, Gender, Work and Organization, vol. 16(6), P. 684-709

Del Boca D., Pasqua S. and Pronzato C. (2009), Motherhood and Market Work Decisions in Institutional Context: a European Perspective, Oxford Economic Papers, vol. 61 (Special Issue)

Del Boca D., Pasqua S., Pronzato C. and Wetzels C. (2007), An Empirical Analysis of the Effects of Social Policies on Fertility, Labour Market Participation and Earnings of European Women, in Social Policies, Labour Markets and Motherhood: a Comparative Analysis of European Countries, D. Del Boca and C. Wetzels (eds.), Cambridge University Press, 2007

Drago R. and Lee Y. (2008), The Parenting of Infants: a Time Use Study, WP 08-02 Population Research Institute, PennState University

Greene, W.H. (2003), Econometric analysis, Fifth edition, Prentice Hall

Gronau R. (1976), Leisure, Home Production and Work. The theory of the allocation of time revisited, NBER Working paper No. 137, May

Gutierrez-Domenech M. (2008), Parental Employment and Time with Children in Spain, La Caixa WP N. 1

Hajivassiliou, V. and McFadden, D. (1990), "The method of simulated scores for the estimation of LDV-models with application to external debt crises", Cowles Foundation Discussion Paper, number 967, Yale University 
Hallberg D. and Klevmarken A. (2003), Time for Children: a Study of Parent's Time Allocation, Journal of Population Economics, vol. 16, p. 205-226

Ichino A. and Sanz de Galdeano A. (2004), Reconciling Motherhood and Work: Evidence form Time Use Data in Three Countries, W.P. n. 114 CSEF Kalenkoski C., Ribar D. and Stratton L. (2008), The Influence of Wages on Parents' Time Allocation of Time to Child Care and Market Work in the United Kingdom, Journal of Population Economics, vol. 22(2), pages 399-419, April

Kalenkoski C.M., Ribar D.C. and Stratton L. (2005), Parental Child Care in Single Parent, Cohabiting, and Married Couple Families: Time Diary Evidence from the United Kingdom, American Economic Review, vol. 95, p. $194-98$

Kalenkoski C.M., Ribar D.C. and Stratton L.S (2006), Parental Child Care in Single Parent, Cohabiting, and Married Couple Families: Time Diary Evidence from the United States and the United Kingdom, WP No. 440 The Levy Economics Institute of Brad College

Keane, M. (1994), "A computationally practical simulation estimator for panel data, Econometrica, 62(1), pp.95-116

Mencarini L. and Tanturri M.L. (2004), Time Use, Family Role-Set and Childbearing among Italian Working Women, Genus, vol. LX, p. III

Nock S.L. and Kingston P.W. (1988), Time with Children: the Impact of Couples' Work-Time Commitments, Social Forces, vol. 67(1), p. 59-85

OECD (2008), Employment Outlook, Paris

Sandberg J.F. and Hoffert S.L. (2001), Changes in Children's Time with Parents: United States, 1981-1997, Demography, vol.38(3), p. 423-436

Sayer L.C., Bianchi S.M. and Robinson J.P. (2004), Are Parents Investing Less in Children? Trends in Mothers' and Fathers' Time with Children, American Journal of Sociology, vol. 110(1), p. 1-43

Tanturri M.L and Mencarini L. (2009), Father's Involvement in Daily Childcare Activities in Italy: Does a Work-Family Reconciliation Issue Exists?, W.P. ChilD n.22/2009

Yen, S.T., Lin, B. and Smallwood D.M. (2003) "Quasi- and Simulated-Likelihood Approaches to Censored Demand Systems: Food Consumption by Food 
Stamp Recipients in the United States," American Journal of Agricultural Economics, American Agricultural Economics Association, vol. 85(2), pages $458-478$

Yeung W., Sandberg J., Davis-Kean P. and Hofferth S. (2001), Children's Time with Fathers in Intact Families, Journal of Marriage and Family, vol. 63, p. 136-54

Zick C.D., Bryant W.K. and Österbacka E. (2001), Mothers' Employment, Parental Involvement, and the Implication for Intermediate Child Outcomes, Social Science Research, vol. 30, p. 25-49 
Table 1

Sample selecton process

\begin{tabular}{|l|c|c|}
\hline & 1988 & 2002 \\
\hline Original sample & 7,175 & 21,411 \\
Couples of working age (18-56) & 3,754 & 8,279 \\
At least one child under 14 & 2,397 & 4,696 \\
$\begin{array}{l}\text { Diary filled not in a weekend or } \\
\text { on a special day }\end{array}$ & 766 & 1,387 \\
$\begin{array}{l}\text { No full-time education, retired, } \\
\text { disable, chronically ill or doing }\end{array}$ & 742 & 1,269 \\
military service & & \\
No missing relevant variables & 665 & 1,259 \\
\hline
\end{tabular}

Table 2

Time allocation (daily minutes) in 1988 and 2002 (unconditional mean)

\begin{tabular}{|l|rr|rr|}
\hline & \multicolumn{5}{|c|}{$\begin{array}{c}\text { Dual earner households } \\
\text { Husband }\end{array}$} & $\begin{array}{r}\text { Male breadwinner households } \\
\text { Wusband }\end{array}$ & Wife \\
\hline \multicolumn{5}{|c|}{$\mathbf{1 9 8 8}$} \\
\hline Work & 456.34 & 300.39 & 464.58 & - \\
Domestic work & 40.63 & 270.75 & 27.61 & 451.56 \\
Basic childcare & 10.71 & 48.49 & 4.67 & 67.91 \\
Quality childcare & 17.03 & 16.50 & 8.42 & 22.12 \\
\hline \multicolumn{5}{|c}{2002} \\
Work & 474.02 & 317.60 & 468.08 & - \\
Domestic work & 39.32 & 211.75 & 23.46 & 398.31 \\
Basic childcare & 24.48 & 72.71 & 13.75 & 110.26 \\
Quality childcare & 23.06 & 32.94 & 24.46 & 46.18 \\
\hline
\end{tabular}


Table 3

Time allocation (daily minutes)

in 1988 and 2002 (conditional mean)

\begin{tabular}{|c|c|c|c|c|c|c|c|c|}
\hline & \multicolumn{4}{|c|}{ Dual earners households } & \multicolumn{4}{|c|}{ Male breadwinner households } \\
\hline & \multicolumn{2}{|c|}{ Husband } & \multicolumn{2}{|c|}{ Wife } & \multicolumn{2}{|c|}{ Husband } & \multicolumn{2}{|c|}{ Wife } \\
\hline & $\%>0$ & $\begin{array}{c}\text { Mean } \\
\text { if }>0\end{array}$ & $\%>0$ & $\begin{array}{c}\text { Mean } \\
\text { if }>0\end{array}$ & $\%>0$ & $\begin{array}{c}\text { Mean } \\
\text { if }>0\end{array}$ & $\%>0$ & $\begin{array}{c}\text { Mean } \\
\text { if }>0\end{array}$ \\
\hline \multicolumn{9}{|c|}{1988} \\
\hline Work & $96.62 \%$ & 472.30 & $78.72 \%$ & 381.61 & $97.94 \%$ & 474.31 & - & - \\
\hline Domestic work & $56.42 \%$ & 72.01 & $99.66 \%$ & 272.66 & $46.33 \%$ & 59.60 & $100.00 \%$ & 451.56 \\
\hline Basic childcare & $24.66 \%$ & 43.43 & $72.30 \%$ & 67.07 & $13.49 \%$ & 34.59 & $76.83 \%$ & 88.38 \\
\hline Quality childcare & $22.63 \%$ & 75.22 & $28.04 \%$ & 58.83 & $16.71 \%$ & 50.35 & $31.38 \%$ & 70.49 \\
\hline \multicolumn{9}{|c|}{2002} \\
\hline Work & $93.80 \%$ & 505.30 & $84.60 \%$ & 375.40 & $91.82 \%$ & 509.76 & - & - \\
\hline Domestic work & $58.25 \%$ & 67.49 & $99.52 \%$ & 212.76 & $41.90 \%$ & 55.98 & $100.00 \%$ & 398.31 \\
\hline Basic childcare & $47.68 \%$ & 51.22 & $83.17 \%$ & 87.42 & $27.26 \%$ & 50.44 & $89.26 \%$ & 123.51 \\
\hline Quality childcare & $39.20 \%$ & 58.82 & $53.65 \%$ & 61.39 & $41.39 \%$ & 59.09 & $61.83 \%$ & 74.68 \\
\hline
\end{tabular}


Time allocation (daily minutes) by educational levels in 1988 and 2002 (unconditional mean)

\begin{tabular}{|c|c|c|c|c|c|c|c|c|c|}
\hline \multirow[b]{2}{*}{ Wife's education } & \multirow[b]{2}{*}{$\begin{array}{l}\text { Husband's } \\
\text { education }\end{array}$} & \multicolumn{4}{|c|}{ Husband } & \multicolumn{4}{|c|}{ Wife } \\
\hline & & Work & $\begin{array}{l}\text { Domestic } \\
\text { work }\end{array}$ & $\begin{array}{c}\text { Basic } \\
\text { childcare }\end{array}$ & $\begin{array}{l}\text { Quality } \\
\text { childcare }\end{array}$ & Work & $\begin{array}{l}\text { Domestic } \\
\text { work }\end{array}$ & $\begin{array}{c}\text { Basic } \\
\text { childcare }\end{array}$ & $\begin{array}{c}\text { Quality } \\
\text { childcare }\end{array}$ \\
\hline \multicolumn{10}{|c|}{ 7. } \\
\hline \multirow[t]{3}{*}{ Compulsory } & Compulsory & 471.72 & 38.11 & 4.26 & 8.19 & 111.27 & 406.87 & 45.17 & 14.96 \\
\hline & Secondary school & 470.88 & 26.49 & 5.13 & 16.88 & 123.25 & 362.28 & 63.33 & 23.71 \\
\hline & University & 348.60 & 54.20 & 2.40 & 35.00 & 168.00 & 347.20 & 38.00 & 0 \\
\hline \multirow[t]{3}{*}{$\begin{array}{l}\text { Secondary } \\
\text { school }\end{array}$} & Compulsory & 452.60 & 32.54 & 10.03 & 21.67 & 200.43 & 316.60 & 84.24 & 25.40 \\
\hline & Secondary school & 404.48 & 47.64 & 12.02 & 13.71 & 153.82 & 330.51 & 69.81 & 23.04 \\
\hline & University & 389.29 & 28.68 & 13.38 & 22.35 & 202.41 & 298.82 & 78.26 & 25.74 \\
\hline \multirow[t]{3}{*}{ University } & Compulsory & 175.00 & 30.00 & 28.33 & 0 & 203.33 & 259.33 & 35.00 & 35.00 \\
\hline & Secondary school & 467.71 & 19.29 & 25.71 & 21.79 & 127.86 & 352.50 & 122.86 & 31.07 \\
\hline & University & 435.10 & 52.35 & 23.90 & 17.50 & 209.25 & 284.65 & 45.20 & 23.75 \\
\hline \multicolumn{10}{|c|}{2002} \\
\hline \multirow[t]{3}{*}{ Compulsory } & Compulsory & 451.37 & 26.76 & 15.74 & 19.33 & 114.75 & 342.95 & 88.29 & 35.19 \\
\hline & Secondary school & 448.59 & 42.15 & 20.44 & 23.48 & 125.78 & 338.59 & 84.67 & 39.19 \\
\hline & University & 335.00 & 40.00 & 10.00 & 6.67 & 48.33 & 436.67 & 35.00 & 11.67 \\
\hline \multirow[t]{3}{*}{$\begin{array}{l}\text { Secondary } \\
\text { school }\end{array}$} & Compulsory & 460.99 & 35.87 & 19.71 & 27.03 & 183.02 & 286.28 & 86.51 & 41.63 \\
\hline & Secondary school & 464.99 & 37.35 & 23.30 & 27.67 & 203.19 & 271.77 & 93.81 & 38.41 \\
\hline & University & 483.57 & 33.57 & 33.75 & 19.11 & 219.11 & 265.89 & 96.96 & 48.39 \\
\hline \multirow[t]{3}{*}{ University } & Compulsory & 488.67 & 28.00 & 28.67 & 40.67 & 173.33 & 246.00 & 113.33 & 70.00 \\
\hline & Secondary school & 424.57 & 43.71 & 20.29 & 27.71 & 211.71 & 230.86 & 119.43 & 50.00 \\
\hline & University & 453.00 & 35.80 & 19.80 & 29.60 & 255.80 & 201.00 & 96.80 & 44.20 \\
\hline
\end{tabular}


Descriptive statistics 1988 and 2002

\begin{tabular}{|c|c|c|}
\hline & 1988 & 2002 \\
\hline Wife's age & 34.01 & 36.45 \\
\hline Husband's age & 37.84 & 39.78 \\
\hline \multicolumn{3}{|l|}{ Wife's education } \\
\hline Compulsory and lower & $63.01 \%$ & $47.02 \%$ \\
\hline Secondary school & $31.43 \%$ & $45.04 \%$ \\
\hline University or higher & $5.56 \%$ & $7.94 \%$ \\
\hline \multicolumn{3}{|l|}{ Husband's education } \\
\hline Compulsory & $60.15 \%$ & $50.68 \%$ \\
\hline Secondary school & $30.98 \%$ & $40.43 \%$ \\
\hline University or higher & $8.87 \%$ & $8.90 \%$ \\
\hline Number of children & 1.95 & 1.84 \\
\hline Highest number of children in the household & 8 & 7 \\
\hline Working wife & & \\
\hline Italy & $45.26 \%$ & $51.15 \%$ \\
\hline North & $57.02 \%$ & $61.66 \%$ \\
\hline Centre & $54.81 \%$ & $59.82 \%$ \\
\hline South & $33.98 \%$ & $37.64 \%$ \\
\hline Other (not sick) adults within the household & $14.29 \%$ & $17.71 \%$ \\
\hline Home owners & $65.56 \%$ & $67.75 \%$ \\
\hline Living in subsidized housing? & $27.37 \%$ & - \\
\hline Poor households & - & $6.43 \%$ \\
\hline Holiday house owners & - & $11.52 \%$ \\
\hline Observations & 665 & 1,259 \\
\hline
\end{tabular}


Table 6

Estimation results for wives - Simultaneous model

\begin{tabular}{|c|c|c|c|c|c|}
\hline & & \multicolumn{2}{|c|}{1988} & \multicolumn{2}{|c|}{2002} \\
\hline & & Coeff. & (St. dev.) & Coeff. & (St. dev.) \\
\hline \multirow[t]{16}{*}{ Work } & Own age & 0.761 & $(3.703)$ & $7.634^{* * \star}$ & $(2.525)$ \\
\hline & Wife's secondary school degree & $130.9^{* * *}$ & $(41.48)$ & $120.6^{\star \star \star}$ & $(25.75)$ \\
\hline & Wife's university degree & $157.0^{\star \star}$ & (79.83) & $194.0^{\star \star \star}$ & $(46.76)$ \\
\hline & Husband's secondary school degree & 17.53 & (41.51) & 26.66 & $(25.18)$ \\
\hline & Husband's university degree & $118.5^{\star}$ & $(67.55)$ & 22.99 & $(44.76)$ \\
\hline & Younger kids less than 3 years old & $-108.2^{* \star}$ & $(48.62)$ & -44.39 & $(30.86)$ \\
\hline & Younger kids between 3 and 5 years old & -39.18 & (46.14) & 34.22 & $(29.64)$ \\
\hline & Number of children & $-68.17^{* * *}$ & (22.73) & $-45.11^{* \star *}$ & (16.33) \\
\hline & Other adults & 72.89 & (51.92) & $57.04^{*}$ & $(30.67)$ \\
\hline & Feeling poor & & & $-104.3^{\star \star \star}$ & (38.88) \\
\hline & Subsidized housing & -42.71 & $(29.10)$ & & \\
\hline & Home ownership & -17.98 & (25.53) & $34.07^{\star *}$ & $(17.24)$ \\
\hline & Holiday house & & & 5.925 & $(23.34)$ \\
\hline & Centre & -37.61 & $(49.18)$ & 13.08 & $(29.91)$ \\
\hline & South & $-197.2^{* * *}$ & (38.83) & $-135.1^{* \star *}$ & $(24.48)$ \\
\hline & Constant & 103.4 & $(133.0)$ & $-250.5^{\star * *}$ & $(95.16)$ \\
\hline \multirow[t]{12}{*}{ Domestic } & Own age & $2.622^{\star \star}$ & $(1.267)$ & 0.556 & $(0.907)$ \\
\hline & Wife's secondary school degree & $-44.70^{* * *}$ & $(14.65)$ & $-51.26^{\star * *}$ & $(9.286)$ \\
\hline & Wife's university degree & $-54.88^{\star}$ & $(29.30)$ & $-102.5^{\star \star \star}$ & $(17.44)$ \\
\hline & Husband's secondary school degree & -22.46 & $(14.52)$ & -8.197 & $(9.123)$ \\
\hline & Husband's university degree & $-61.40^{\star *}$ & $(24.71)$ & -23.87 & $(16.62)$ \\
\hline & Younger kids less than 3 years old & 8.922 & $(16.89)$ & $-36.41^{* * *}$ & $(11.19)$ \\
\hline & Younger kids between 3 and 5 years old & 2.503 & $(16.15)$ & $-24.63^{\star \star}$ & $(10.82)$ \\
\hline & Number of children & $34.97^{* \star *}$ & $(7.538)$ & $22.42^{\star \star *}$ & $(5.847)$ \\
\hline & Other adults & -27.03 & $(18.33)$ & $-22.01^{\star \star}$ & $(11.23)$ \\
\hline & Centre & -0.709 & $(17.74)$ & 11.99 & $(11.17)$ \\
\hline & South & $47.25^{\star \star *}$ & $(13.30)$ & $59.07^{\star \star *}$ & $(8.763)$ \\
\hline & Constant & $218.7^{\star \star \star}$ & $(45.23)$ & $269.9^{\star \star \star}$ & (33.87) \\
\hline \multirow[t]{12}{*}{ Basic care } & Own age & $-1.469^{* *}$ & $(0.623)$ & $-3.067^{* * *}$ & $(0.543)$ \\
\hline & Wife's secondary school degree & $21.37^{\star \star \star}$ & $(7.007)$ & 8.489 & $(5.573)$ \\
\hline & Wife's university degree & $33.39^{* *}$ & $(13.93)$ & 11.01 & $(10.40)$ \\
\hline & Husband's secondary school degree & 2.410 & $(6.968)$ & 3.326 & $(5.472)$ \\
\hline & Husband's university degree & -7.608 & $(11.98)$ & 15.29 & $(9.969)$ \\
\hline & Younger kids less than 3 years old & $98.67^{\star \star \star}$ & (8.089) & $101.5^{\star \star \star}$ & $(6.668)$ \\
\hline & Younger kids between 3 and 5 years old & $53.44^{* * *}$ & $(7.758)$ & $48.55^{\star \star *}$ & $(6.449)$ \\
\hline & Number of children & 4.433 & $(3.660)$ & $21.69^{* \star *}$ & $(3.508)$ \\
\hline & Other adults & -8.528 & $(9.232)$ & $-20.93^{\star * \star}$ & $(6.848)$ \\
\hline & Centre & -4.791 & $(8.677)$ & -4.912 & $(6.714)$ \\
\hline & South & 1.043 & $(6.460)$ & -2.285 & $(5.251)$ \\
\hline & Constant & $37.87^{*}$ & (21.93) & $115.2^{\star \star \star}$ & $(20.26)$ \\
\hline
\end{tabular}


Table 6 (cont.)

Estimation results for wives - Simultaneous model

\begin{tabular}{|l|l|lc|ll|}
\hline \multirow{2}{*}{$\begin{array}{l}\text { Quality } \\
\text { care }\end{array}$} & \multicolumn{2}{|c|}{1988} & \multicolumn{2}{c|}{2002} \\
& Own age & Coeff. & (St. dev.) & Coeff. & (St. dev.) \\
& Wife's secondary school degree & $-2.273^{\star *}$ & $(1.101)$ & -0.368 & $(0.542)$ \\
& Wife's university degree & 13.41 & $(12.27)$ & 8.239 & $(5.571)$ \\
& Husband's secondary school degree & 37.19 & $(23.64)$ & 16.37 & $(10.20)$ \\
& Husband's university degree & 15.80 & $(12.23)$ & -1.576 & $(5.450)$ \\
& Younger kids less than 3 years old & 16.06 & $(20.50)$ & 3.025 & $(9.819)$ \\
& Younger kids between 3 and 5 years old & 4.923 & $(14.11)$ & $42.28^{* * *}$ & $(6.613)$ \\
& Number of children & 9.815 & $(13.59)$ & $19.76^{* * *}$ & $(6.447)$ \\
& Other adults & 0.920 & $(15.94)$ & $-15.52^{* *}$ & $(6.890)$ \\
& Centre & -8.254 & $(14.99)$ & 0.756 & $(6.620)$ \\
& South & $-25.17^{* *}$ & $(11.45)$ & $-11.11^{* *}$ & $(5.267)$ \\
& Constant & -1.334 & $(38.14)$ & 13.95 & $(20.17)$ \\
\hline
\end{tabular}

${ }^{*}$ significant at 10\%;** significant at $5 \% ;{ }^{* * *}$ significant at $1 \%$ 


\begin{tabular}{|c|c|c|c|c|c|}
\hline \multicolumn{6}{|c|}{ EstImation results for nusbands - Simultaneous model } \\
\hline & & \multicolumn{2}{|c|}{1988} & \multicolumn{2}{|c|}{2002} \\
\hline & & Coeff. & (St. dev.) & Coeff. & (St. dev.) \\
\hline \multirow[t]{16}{*}{ Work } & Own age & -0.578 & $(1.296)$ & $-3.980^{* * *}$ & $(1.241)$ \\
\hline & Wife's secondary school degree & $-50.59^{\star \star \star}$ & $(15.65)$ & 15.16 & (13.95) \\
\hline & Wife's university degree & -28.52 & $(31.26)$ & -3.822 & $(26.22)$ \\
\hline & Husband's secondary school degree & -10.19 & $(15.58)$ & -4.859 & $(13.83)$ \\
\hline & Husband's university degree & -37.47 & $(26.46)$ & 12.99 & $(25.19)$ \\
\hline & Younger kids less than 3 years old & -8.194 & $(18.06)$ & -16.00 & $(16.61)$ \\
\hline & Younger kids between 3 and 5 years old & -7.339 & $(16.90)$ & 3.664 & $(16.15)$ \\
\hline & Number of children & -0.110 & $(8.107)$ & $19.38^{\star *}$ & $(8.823)$ \\
\hline & Other adults & -10.83 & $(19.53)$ & -10.10 & $(16.87)$ \\
\hline & Feeling poor & & & $-57.50^{\star * \star}$ & $(22.21)$ \\
\hline & Subsidized housing & $-24.44^{*}$ & $(13.20)$ & & \\
\hline & Home ownership & $21.73^{\star}$ & $(12.27)$ & $23.91^{\star *}$ & $(11.67)$ \\
\hline & Holiday house & & & -12.78 & $(16.87)$ \\
\hline & Centre & -20.59 & $(18.95)$ & $29.06^{*}$ & $(16.85)$ \\
\hline & South & $-40.43^{\star * \star}$ & $(14.13)$ & $-41.80^{* \star *}$ & $(13.20)$ \\
\hline & Constant & $515.3^{\star \star \star}$ & $(50.20)$ & $573.0^{\star \star \star}$ & $(51.16)$ \\
\hline \multirow[t]{12}{*}{ Domestic } & Own age & 0.0157 & $(0.959)$ & $1.916^{\star \star \star}$ & $(0.574)$ \\
\hline & Wife's secondary school degree & 8.349 & $(11.50)$ & 3.824 & $(6.382)$ \\
\hline & Wife's university degree & 9.426 & $(22.75)$ & 11.40 & $(11.77)$ \\
\hline & Husband's secondary school degree & 2.900 & $(11.47)$ & $17.67^{\star \star \star}$ & $(6.294)$ \\
\hline & Husband's university degree & 11.64 & $(19.14)$ & 8.078 & $(11.38)$ \\
\hline & Younger kids less than 3 years old & 15.16 & $(13.43)$ & 9.279 & $(7.656)$ \\
\hline & Younger kids between 3 and 5 years old & -2.877 & $(12.53)$ & 8.427 & $(7.438)$ \\
\hline & Number of children & 6.616 & $(5.946)$ & -4.470 & $(4.065)$ \\
\hline & Other adults & 13.32 & $(14.60)$ & -6.331 & $(7.833)$ \\
\hline & Centre & -21.62 & (14.05) & $-29.06^{\star \star \star}$ & $(7.855)$ \\
\hline & South & $-25.90^{* *}$ & $(10.45)$ & $-16.66^{\star * *}$ & $(6.049)$ \\
\hline & Constant & -12.11 & (37.45) & $-69.94^{* \star *}$ & $(23.74)$ \\
\hline \multirow[t]{12}{*}{ Basic care } & Own age & 0.0429 & $(0.890)$ & $1.027^{*}$ & $(0.562)$ \\
\hline & Wife's secondary school degree & $34.69^{\star \star \star}$ & $(10.23)$ & $13.69^{\star \star}$ & $(6.379)$ \\
\hline & Wife's university degree & $62.88^{* \star \star}$ & $(18.31)$ & 6.922 & $(11.46)$ \\
\hline & Husband's secondary school degree & 2.449 & $(10.27)$ & 10.16 & $(6.290)$ \\
\hline & Husband's university degree & 6.797 & $(15.97)$ & $20.58^{*}$ & $(11.04)$ \\
\hline & Younger kids less than 3 years old & $34.63^{* \star *}$ & $(12.06)$ & $48.88^{\star \star *}$ & $(7.518)$ \\
\hline & Younger kids between 3 and 5 years old & 16.62 & $(11.68)$ & $37.23^{\star \star \star}$ & (7.332) \\
\hline & Number of children & -0.297 & $(5.823)$ & 2.169 & $(4.045)$ \\
\hline & Other adults & -14.30 & $(15.00)$ & $-24.12^{\star \star *}$ & $(8.114)$ \\
\hline & Centre & -10.78 & $(12.71)$ & $-19.97^{\star \star}$ & $(7.868)$ \\
\hline & South & $-17.83^{*}$ & $(9.754)$ & -8.018 & $(5.984)$ \\
\hline & Constant & $-90.50^{\star \star \star}$ & $(35.04)$ & $-97.08^{\star \star \star}$ & (23.28) \\
\hline
\end{tabular}


Table 7 (cont.)

\begin{tabular}{|c|c|c|c|c|c|}
\hline \multicolumn{6}{|c|}{ Estımation results for husbands - Simultaneous model } \\
\hline & & \multicolumn{2}{|c|}{1988} & \multicolumn{2}{|c|}{2002} \\
\hline & & Coeff. & (St. dev.) & Coeff. & (St. dev.) \\
\hline \multirow[t]{12}{*}{$\begin{array}{l}\text { Quality } \\
\text { care }\end{array}$} & Own age & $-2.489^{* *}$ & (1.192) & $-0.955^{\star}$ & $(0.517)$ \\
\hline & Wife's secondary school degree & 14.60 & (13.72) & $10.28^{*}$ & $(5.861)$ \\
\hline & Wife's university degree & 20.27 & (25.85) & 15.47 & $(10.59)$ \\
\hline & Husband's secondary school degree & 5.371 & (13.79) & 3.419 & $(5.769)$ \\
\hline & Husband's university degree & $39.92^{\star}$ & (21.95) & 1.426 & $(10.38)$ \\
\hline & Younger kids less than 3 years old & $65.13^{* * *}$ & $(16.90)$ & $55.17^{\star \star *}$ & $(6.856)$ \\
\hline & Younger kids between 3 and 5 years old & $57.60^{\star \star \star}$ & $(16.16)$ & $35.47^{\star \star \star}$ & $(6.740)$ \\
\hline & Number of children & -2.727 & $(7.993)$ & $-8.107^{\star \star}$ & $(3.738)$ \\
\hline & Other adults & -8.758 & (20.44) & $-23.84^{\star \star \star}$ & $(7.701)$ \\
\hline & Centre & 6.817 & $(17.07)$ & -5.970 & (7.097) \\
\hline & South & -20.71 & (13.08) & -7.334 & $(5.540)$ \\
\hline & Constant & -30.96 & (45.87) & 10.71 & $(21.00)$ \\
\hline
\end{tabular}

significant at $10 \% ;{ }^{* *}$ significant at $5 \% ;{ }^{* * *}$ significant at $1 \%$ 
Table 8

Correlation matrix - Simultaneous model

\begin{tabular}{|c|c|c|c|c|c|c|c|c|}
\hline \\
\hline \multicolumn{9}{|c|}{1988} \\
\hline & $\begin{array}{l}\text { Wife's } \\
\text { work }\end{array}$ & $\begin{array}{l}\text { Husband's } \\
\text { work }\end{array}$ & $\begin{array}{c}\text { Wife's } \\
\text { domestic }\end{array}$ & $\begin{array}{l}\text { Husband's } \\
\text { domestic }\end{array}$ & $\begin{array}{c}\text { Wife's } \\
\text { basic care }\end{array}$ & $\begin{array}{l}\text { Husband's } \\
\text { basic care }\end{array}$ & $\begin{array}{l}\text { Wife's } \\
\text { quality } \\
\text { care }\end{array}$ & $\begin{array}{l}\text { Husband's } \\
\text { quality } \\
\text { care }\end{array}$ \\
\hline Wife's work & $376.37^{* \star *}$ & $0.079^{*}$ & $-0.758^{\star * *}$ & 0.070 & $-0.304^{\star * *}$ & $0.119^{*}$ & $-0.117^{* *}$ & $0.135^{\star \star}$ \\
\hline Husband's work & & $157.67^{* \star *}$ & $0.081^{* *}$ & $-0.446^{\star * *}$ & 0.048 & $-0.257^{* * *}$ & 0.008 & $-0.173^{\star \star *}$ \\
\hline Wife's domestic & & & $147.91^{* * *}$ & $-0.113^{* * *}$ & $0.074^{*}$ & $-0.115^{\star \star}$ & -0.041 & $-0.144^{\star \star}$ \\
\hline Husband's domestic & & & & $106.64^{\star \star \star}$ & -0.003 & $0.274^{\star * \star}$ & 0.034 & 0.041 \\
\hline Wife's basic care & & & & & $68.79^{* * *}$ & $0.189^{* * *}$ & $0.192^{* \star *}$ & $0.101^{*}$ \\
\hline Husband's basic care & & & & & & $75.77^{\star * *}$ & $0.221^{* * *}$ & $0.231^{\star * *}$ \\
\hline Wife's quality care & & & & & & & $101.65^{\star * *}$ & $0.422^{\star \star *}$ \\
\hline Husband's quality care & & & & & & & & $104.30^{* * *}$ \\
\hline \multicolumn{9}{|c|}{2002} \\
\hline & $\begin{array}{l}\text { Wife's } \\
\text { work }\end{array}$ & $\begin{array}{l}\text { Husband's } \\
\text { work }\end{array}$ & $\begin{array}{l}\text { Wife's } \\
\text { domestic }\end{array}$ & $\begin{array}{l}\text { Husband's } \\
\text { domestic }\end{array}$ & $\begin{array}{l}\text { Wife's } \\
\text { basic care }\end{array}$ & $\begin{array}{l}\text { Husband's } \\
\text { basic care }\end{array}$ & $\begin{array}{l}\text { Wife's } \\
\text { quality } \\
\text { care }\end{array}$ & $\begin{array}{l}\text { Husband's } \\
\text { quality } \\
\text { care }\end{array}$ \\
\hline Wife's work & $346.05^{\star \star \star}$ & $0.109^{\star * *}$ & $-0.734^{\star * *}$ & $0.143^{* * *}$ & $-0.274^{\star * *}$ & $0.226^{* * *}$ & $-0.221^{* * *}$ & -0.033 \\
\hline Husband's work & & $206.54^{* * *}$ & $0.049^{*}$ & $-0.434^{\star * *}$ & $0.100^{\star \star \star}$ & $-0.249^{* * *}$ & $0.085^{\star \star \star}$ & $-0.222^{\star * \star}$ \\
\hline Wife's domestic & & & $137.55^{\star * *}$ & $-0.111^{* * *}$ & $0.095^{\star * \star}$ & $-0.224^{\star * *}$ & $0.078^{* *}$ & -0.005 \\
\hline Husband's domestic & & & & $87.23^{\star \star \star}$ & -0.039 & $0.265^{\star \star \star}$ & -0.017 & $0.156^{\star \star \star}$ \\
\hline Wife's basic care & & & & & $80.98^{* * *}$ & $0.116^{\star \star *}$ & $0.138^{\star * *}$ & $0.113^{\star \star \star}$ \\
\hline Husband's basic care & & & & & & $80.61^{* \star \star}$ & -0.012 & $0.169^{\star \star \star}$ \\
\hline Wife's quality care & & & & & & & $76.17^{\star \star *}$ & $0.202^{* * *}$ \\
\hline Husband's quality care & & & & & & & & $74.51^{\star \star \star}$ \\
\hline
\end{tabular}

Note: Standard deviations on main diagonal. Correlation coefficients off-diagonal.

* significant at $10 \%$;* significant at $5 \%$; ${ }^{* * *}$ significant at $1 \%$ 
Estimation results for wives - Sequential model

\begin{tabular}{|c|c|c|c|c|c|}
\hline & & \multicolumn{2}{|c|}{1988} & \multicolumn{2}{|c|}{2002} \\
\hline & & Coeff. & (St. dev.) & Coeff. & (St. dev.) \\
\hline \multirow[t]{16}{*}{ Work } & Own age & 0.495 & $(3.941)$ & $8.215^{\star \star \star}$ & $(2.882)$ \\
\hline & Wife's secondary school degree & $103.7^{* *}$ & $(45.52)$ & $134.8^{* * *}$ & $(28.91)$ \\
\hline & Wife's university degree & 138.5 & $(87.44)$ & $202.1^{* \star *}$ & $(51.97)$ \\
\hline & Husband's secondary school degree & 9.918 & $(45.61)$ & 18.65 & $(28.12)$ \\
\hline & Husband's university degree & 109.9 & $(74.27)$ & 18.61 & $(49.46)$ \\
\hline & Younger kids less than 3 years old & $-226.7^{\star \star *}$ & $(54.22)$ & -47.65 & $(34.58)$ \\
\hline & Younger kids between 3 and 5 years old & -80.56 & $(50.45)$ & 40.35 & $(32.97)$ \\
\hline & Number of children & $-87.07^{\star \star \star}$ & $(25.78)$ & $-51.52^{\star \star *}$ & $(18.49)$ \\
\hline & Other adults & 53.63 & $(57.16)$ & $72.01^{* *}$ & $(34.10)$ \\
\hline & Feeling poor & & & $-210.7^{\star * *}$ & $(52.92)$ \\
\hline & Subsidized housing & -34.89 & (34.02) & & \\
\hline & Home ownership & 11.80 & $(30.06)$ & $59.91^{\star *}$ & $(24.62)$ \\
\hline & Holiday house & & & -0.0204 & $(32.55)$ \\
\hline & Centre & -29.08 & $(53.53)$ & 12.49 & (33.01) \\
\hline & South & $-204.3^{\star \star \star}$ & $(42.62)$ & $-135.7^{* \star *}$ & $(27.43)$ \\
\hline & Constant & 162.6 & $(142.5)$ & $-299.7^{\star \star \star}$ & $(108.5)$ \\
\hline \multirow[t]{14}{*}{ Domestic } & Own age & $2.473^{* \star}$ & $(1.096)$ & -0.713 & $(0.926)$ \\
\hline & Wife's secondary school degree & $-53.71^{*}$ & $(29.21)$ & -23.59 & $(16.56)$ \\
\hline & Wife's university degree & -52.29 & $(38.90)$ & $-89.10^{\star \star \star}$ & $(30.61)$ \\
\hline & Husband's secondary school degree & -25.71 & $(18.72)$ & -8.817 & $(15.94)$ \\
\hline & Husband's university degree & $-58.40^{*}$ & $(35.21)$ & -14.53 & $(28.86)$ \\
\hline & Younger kids less than 3 years old & $-37.52^{\star}$ & $(20.82)$ & $-48.50^{\star \star \star}$ & $(17.77)$ \\
\hline & Younger kids between 3 and 5 years old & -13.74 & $(19.85)$ & -14.31 & $(18.11)$ \\
\hline & Number of children & 11.53 & $(9.402)$ & $31.78^{\star \star \star}$ & $(10.15)$ \\
\hline & Other adults & -13.20 & $(23.33)$ & -31.40 & $(19.50)$ \\
\hline & Centre & -20.76 & $(24.13)$ & $42.07^{\star *}$ & $(20.07)$ \\
\hline & South & $-48.74^{*}$ & $(25.97)$ & 7.028 & $(16.83)$ \\
\hline & Husband's work time & $-0.891^{*}$ & $(0.468)$ & $-1.062^{\star \star \star}$ & $(0.168)$ \\
\hline & Wife's work time & $-0.670^{* \star *}$ & $(0.0603)$ & $-0.171^{\star \star \star}$ & $(0.0450)$ \\
\hline & Constant & $831.2^{\star \star \star}$ & $(247.6)$ & $817.2^{\star \star \star}$ & $(87.39)$ \\
\hline \multirow[t]{14}{*}{ Basic care } & Own age & $-1.404^{*}$ & $(0.718)$ & $-2.420^{\star \star \star}$ & $(0.595)$ \\
\hline & Wife's secondary school degree & 1.682 & $(16.09)$ & $27.40^{\star \star \star}$ & $(7.326)$ \\
\hline & Wife's university degree & 19.68 & $(19.26)$ & $33.43^{* *}$ & $(13.08)$ \\
\hline & Husband's secondary school degree & -0.867 & $(9.055)$ & 5.491 & $(6.651)$ \\
\hline & Husband's university degree & -24.13 & $(17.84)$ & $19.81^{*}$ & $(12.04)$ \\
\hline & Younger kids less than 3 years old & $102.6^{\star \star \star}$ & $(10.57)$ & $92.73^{\star \star \star}$ & $(7.850)$ \\
\hline & Younger kids between 3 and 5 years old & $51.82^{\star \star \star}$ & $(9.904)$ & $52.01^{* * *}$ & $(7.794)$ \\
\hline & Number of children & $9.014^{*}$ & $(4.690)$ & $18.84^{\star \star \star}$ & $(4.562)$ \\
\hline & Other adults & -16.00 & $(11.64)$ & $-17.27^{\star \star}$ & $(8.469)$ \\
\hline & Centre & -8.208 & (12.09) & 3.450 & (8.712) \\
\hline & South & 5.823 & (14.28) & $-24.80^{\star \star \star}$ & (8.003) \\
\hline & Husband's work time & -0.243 & $(0.281)$ & $-0.235^{\star \star}$ & $(0.117)$ \\
\hline & Wife's work time & $0.176^{\star \star \star}$ & $(0.0294)$ & $-0.240^{\star \star \star}$ & $(0.0389)$ \\
\hline & Constant & 122.2 & $(145.9)$ & $240.3^{\star \star \star}$ & (59.98) \\
\hline
\end{tabular}


Table 9 (cont.)

\begin{tabular}{|c|c|c|c|c|c|}
\hline \multicolumn{6}{|c|}{ Estimation results for wives - Sequential model } \\
\hline & & \multicolumn{2}{|c|}{1988} & \multicolumn{2}{|c|}{2002} \\
\hline & & Coeff. & (St. dev.) & Coeff. & (St. dev.) \\
\hline \multirow[t]{15}{*}{$\begin{array}{l}\text { Quality } \\
\text { care }\end{array}$} & Own age & $-3.714^{\star *}$ & (1.718) & $-2.031^{\star *}$ & $(1.010)$ \\
\hline & Wife's secondary school degree & -49.64 & $(67.21)$ & $45.13^{\star \star \star}$ & $(12.49)$ \\
\hline & Wife's university degree & 21.57 & (70.00) & $58.11^{\star \star \star}$ & $(20.72)$ \\
\hline & Husband's secondary school degree & 4.695 & $(31.38)$ & 5.729 & $(10.04)$ \\
\hline & Husband's university degree & -50.71 & $(66.60)$ & 26.27 & $(18.65)$ \\
\hline & Younger kids less than 3 years old & 102.2 & $(67.04)$ & $117.5^{\star \star \star}$ & $(25.14)$ \\
\hline & Younger kids between 3 and 5 years old & 52.28 & $(42.21)$ & $65.42^{* * *}$ & $(16.55)$ \\
\hline & Number of children & 14.07 & $(16.41)$ & $15.23^{*}$ & $(8.157)$ \\
\hline & Other adults & -23.38 & $(40.56)$ & $-25.09^{\star}$ & (13.02) \\
\hline & Centre & -40.46 & $(43.19)$ & 11.75 & (12.91) \\
\hline & South & -85.78 & $(59.29)$ & $-50.00^{* * *}$ & $(13.16)$ \\
\hline & Husband's work time & -1.704 & $(1.247)$ & $-0.406^{\star \star}$ & $(0.174)$ \\
\hline & Wife's work time & 0.0856 & $(0.133)$ & $-0.387^{* * *}$ & $(0.0773)$ \\
\hline & Own basic care time & $-1.256^{\star *}$ & $(0.598)$ & $-0.945^{\star * *}$ & $(0.255)$ \\
\hline & Constant & 893.7 & $(628.5)$ & $339.6^{\star \star *}$ & $(102.9)$ \\
\hline
\end{tabular}

${ }^{*}$ significant at $10 \% ;{ }^{* *}$ significant at $5 \% ;{ }^{* * *}$ significant at $1 \%$ 
Estimation results for husbands - Sequential model

\begin{tabular}{|c|c|c|c|c|c|}
\hline & & \multicolumn{2}{|c|}{1988} & \multicolumn{2}{|c|}{2002} \\
\hline & & Coeff. & (St. dev.) & Coeff. & (St. dev.) \\
\hline Work & $\begin{array}{l}\text { Own age } \\
\text { Wife's secondary school degree } \\
\text { Wife's university degree } \\
\text { Husband's secondary school degree } \\
\text { Husband's university degree } \\
\text { Younger kids less than } 3 \text { years old } \\
\text { Younger kids between } 3 \text { and } 5 \text { years old } \\
\text { Number of children } \\
\text { Other adults } \\
\text { Feeling poor } \\
\text { Subsidized housing } \\
\text { Home ownership } \\
\text { Holiday house } \\
\text { Centre } \\
\text { South } \\
\text { Constant }\end{array}$ & $\begin{array}{l}-0.382 \\
-49.94^{\star * *} \\
-26.71 \\
-5.660 \\
-29.98 \\
-11.24 \\
-8.260 \\
-0.712 \\
-9.623 \\
\\
2.157 \\
7.123^{\star} \\
-18.54 \\
-42.69^{* * *} \\
510.9^{* \star *}\end{array}$ & $\begin{array}{l}(0.715) \\
(15.63) \\
(31.22) \\
(15.48) \\
(26.23) \\
(16.11) \\
(15.93) \\
(7.632) \\
(19.22) \\
(3.765) \\
(4.203) \\
(18.94) \\
(14.09) \\
(31.45)\end{array}$ & $\begin{array}{l}-2.446^{\star \star \star} \\
-1.773 \\
9.700 \\
16.46 \\
-6.169 \\
-7.434 \\
10.06 \\
16.20^{\star} \\
-12.67 \\
-22.11^{\star *} \\
\\
3.156 \\
2.081 \\
31.25^{\star} \\
-40.16^{\star * *} \\
522.1^{\star * \star} \\
\end{array}$ & $\begin{array}{l}(0.658) \\
(13.78) \\
(24.94) \\
(13.93) \\
(26.17) \\
(15.07) \\
(15.37) \\
(8.593) \\
(16.57) \\
(9.367) \\
(4.681) \\
(6.431) \\
(16.90) \\
(13.22) \\
(31.97)\end{array}$ \\
\hline Domestic & $\begin{array}{l}\text { Own age } \\
\text { Wife's secondary school degree } \\
\text { Wife's university degree } \\
\text { Husband's secondary school degree } \\
\text { Husband's university degree } \\
\text { Younger kids less than } 3 \text { years old } \\
\text { Younger kids between } 3 \text { and } 5 \text { years old } \\
\text { Number of children } \\
\text { Other adults } \\
\text { Centre } \\
\text { South } \\
\text { Husband's work time } \\
\text { Wife's work time } \\
\text { Constant }\end{array}$ & \begin{tabular}{|l}
0.387 \\
$84.20^{\star \star}$ \\
50.31 \\
14.19 \\
65.01 \\
36.12 \\
9.330 \\
11.33 \\
24.74 \\
10.31 \\
48.11 \\
$1.677^{\star \star *}$ \\
0.0530 \\
$-880.5^{\star * \star}$
\end{tabular} & $\begin{array}{l}(1.589) \\
(39.57) \\
(63.80) \\
(31.14) \\
(55.31) \\
(33.29) \\
(32.26) \\
(15.49) \\
(38.83) \\
(38.99) \\
(35.65) \\
(0.517) \\
(0.0498) \\
(269.7)\end{array}$ & \begin{tabular}{|l}
0.0463 \\
6.579 \\
-1.799 \\
$15.05^{\star}$ \\
11.67 \\
7.774 \\
12.93 \\
7.526 \\
$-17.71^{*}$ \\
-12.11 \\
$-36.56^{\star * *}$ \\
$-0.659^{\star \star *}$ \\
$0.105^{\star \star \star}$ \\
$273.8^{\star * \star}$
\end{tabular} & $\begin{array}{l}(0.658) \\
(8.651) \\
(15.36) \\
(7.930) \\
(14.37) \\
(9.368) \\
(9.155) \\
(5.471) \\
(9.915) \\
(10.53) \\
(9.721) \\
(0.141) \\
(0.0380) \\
(78.23)\end{array}$ \\
\hline Basic care & $\begin{array}{l}\text { Own age } \\
\text { Wife's secondary school degree } \\
\text { Wife's university degree } \\
\text { Husband's secondary school degree } \\
\text { Husband's university degree } \\
\text { Younger kids less than } 3 \text { years old } \\
\text { Younger kids between } 3 \text { and } 5 \text { years old } \\
\text { Number of children } \\
\text { Other adults } \\
\text { Centre } \\
\text { South } \\
\text { Husband's work time } \\
\text { Wife's work time } \\
\text { Constant }\end{array}$ & \begin{tabular}{|l}
0.0853 \\
$42.69^{\star \star}$ \\
$64.43^{\star \star \star}$ \\
3.117 \\
11.49 \\
$47.08^{\star \star \star}$ \\
21.30 \\
5.917 \\
-14.79 \\
-2.569 \\
13.99 \\
0.374 \\
$0.170^{\star \star \star}$ \\
$-318.1^{\star}$ \\
\end{tabular} & $\begin{array}{l}(0.961) \\
(19.40) \\
(24.53) \\
(12.73) \\
(23.11) \\
(14.81) \\
(13.98) \\
(6.985) \\
(17.48) \\
(16.43) \\
(17.53) \\
(0.314) \\
(0.0542) \\
(165.0)\end{array}$ & \begin{tabular}{|l}
-0.206 \\
$13.23^{\star}$ \\
-4.569 \\
8.087 \\
$22.55^{\star}$ \\
$49.46^{* \star *}$ \\
$40.22^{* \star *}$ \\
$9.880^{\star}$ \\
$-31.28^{\star * *}$ \\
-10.79 \\
$-17.84^{\star}$ \\
$-0.384^{\star *}$ \\
$0.0914^{* *}$ \\
103.4
\end{tabular} & $\begin{array}{l}(0.666) \\
(7.991) \\
(13.30) \\
(6.853) \\
(12.16) \\
(8.323) \\
(7.985) \\
(5.043) \\
(8.973) \\
(9.509) \\
(9.486) \\
(0.159) \\
(0.0449) \\
(86.55)\end{array}$ \\
\hline
\end{tabular}


Table 10 (cont.)

Estimation results for husbands - Sequential model

\begin{tabular}{|l|l|ll|ll|}
\hline \multirow{2}{*}{$\begin{array}{l}\text { Quality } \\
\text { care }\end{array}$} & \multicolumn{2}{|c|}{1988} & \multicolumn{2}{c|}{2002} \\
& Own age & Coeff. & (St. dev.) & Coeff. & (St. dev.) \\
& Wife's secondary school degree & $-2.400^{* *}$ & $(1.217)$ & $-2.655^{* * *}$ & $(0.847)$ \\
& Wife's university degree & 15.92 & $(29.52)$ & $23.82^{* *}$ & $(11.87)$ \\
& Husband's secondary school degree & 24.99 & $(31.57)$ & 8.210 & $(21.02)$ \\
& Husband's university degree & 5.649 & $(14.50)$ & 2.516 & $(10.97)$ \\
& Younger kids less than 3 years old & 38.50 & $(28.80)$ & 10.60 & $(19.90)$ \\
& Younger kids between 3 and 5 years old & $61.15^{\star * *}$ & $(20.99)$ & $56.83^{\star * *}$ & $(12.91)$ \\
& Number of children & -5.885 & $(8.979)$ & 4.449 & $(7.735)$ \\
& Other adults & -6.483 & $(21.21)$ & $-37.82^{* * *}$ & $(14.05)$ \\
& Centre & 5.436 & $(19.71)$ & 15.01 & $(14.84)$ \\
& South & -34.45 & $(27.47)$ & $-40.26^{* * *}$ & $(13.90)$ \\
& Husband's work time & -0.135 & $(0.533)$ & $-0.850^{* * *}$ & $(0.223)$ \\
& Wife's work time & -0.0750 & $(0.0807)$ & 0.0157 & $(0.0391)$ \\
& Own basic care time & -0.281 & $(0.360)$ & $-0.331^{* *}$ & $(0.134)$ \\
& Constant & 51.69 & $(282.8)$ & $450.2^{* * *}$ & $(120.4)$ \\
\hline
\end{tabular}

significant at $10 \% ;{ }^{* *}$ significant at $5 \%$; ${ }^{* * *}$ significant at $1 \%$ 


\section{Table 11}

Correlation matrix - Sequential model

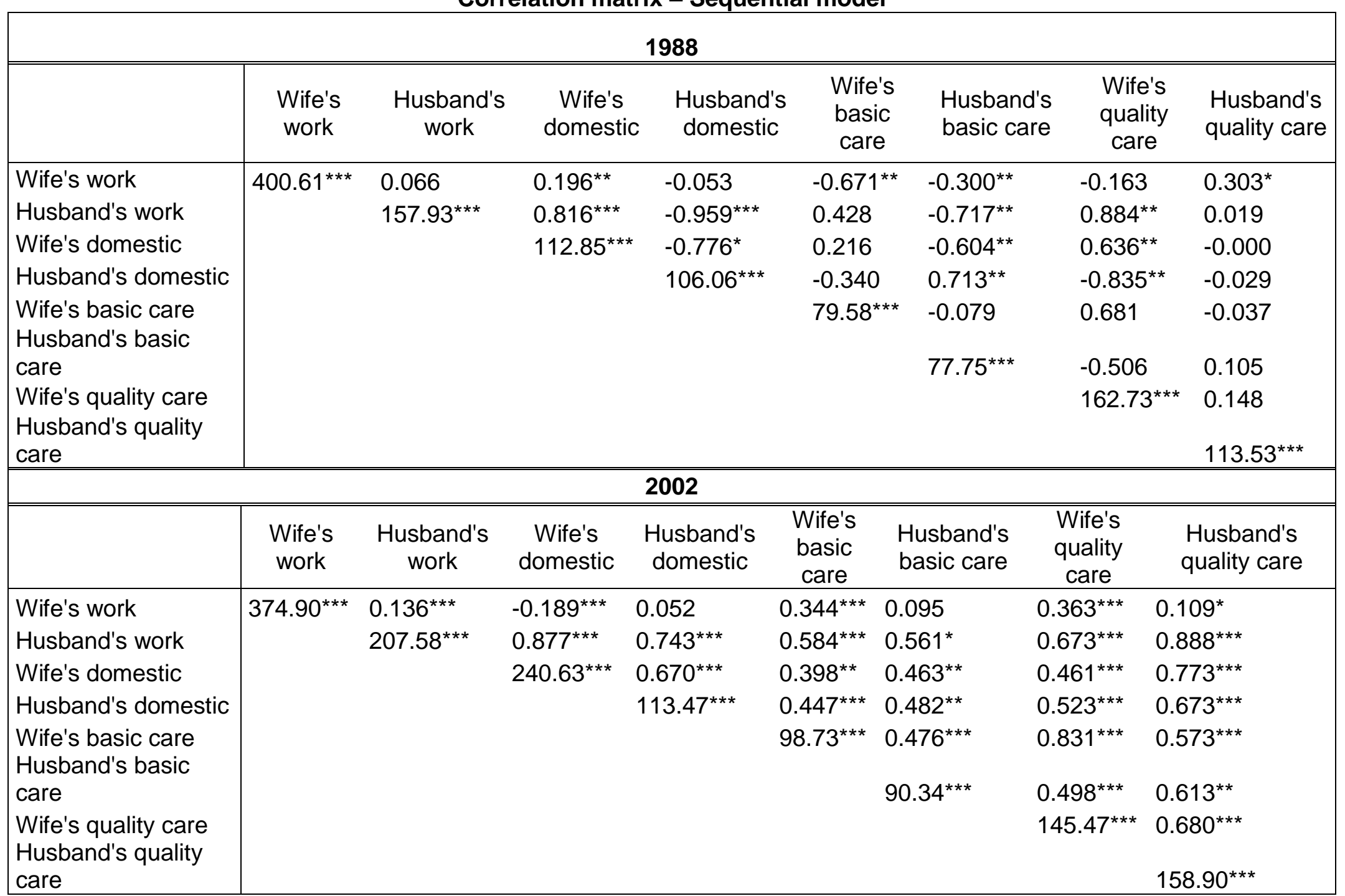

Note: Standard deviations on main diagonal. Correlation coefficients off-diagonal.

* significant at $10 \% ;{ }^{* *}$ significant at $5 \%$; ${ }^{* * *}$ significant at $1 \%$. 